\title{
Applications of Cyclometalation Five-Membered Ring Products and Intermediates as Catalytic Agents
}

\author{
Iwao Omae \\ Omae Research Laboratories, Saitama, Japan \\ Email: um5i-oome@asahi-net.or.jp
}

Received 23 February 2016; accepted 11 June 2016; published 14 June 2016

Copyright (C) 2016 by author and Scientific Research Publishing Inc.

This work is licensed under the Creative Commons Attribution International License (CC BY). http://creativecommons.org/licenses/by/4.0/

c) (i) Open Access

\section{Abstract}

The five-membered ring products and intermediates of cyclometalation reactions are very easily synthesized via donation from a hetero atom to a metal atom, which leads to the very high functionality of the product. This functionality is caused by the donation of the hetero atom and various types of metal atoms, halogen atom and other ligands such as alkanes, alkenes, alkynes, $\mathrm{Cp}$, $\mathrm{Cp}^{*}$, aryl groups and heterocyclic compounds. These products have three types of catalytic applications: cyclometalation five-membered ring products as catalysts, cyclometalation five-membered ring intermediates as catalyst agents and cyclometalation five-membered ring intermediates with unconventional substrates and as catalyst actions. Because of the high functionality of these products, the applications of them have been increasing not only as the metathesis in the first and second generations of Hoveyda-Grubbs catalysts but also as in chiral reactions, crosscoupling reactions and polymerization reactions. The above cyclometalation products have been utilized for the production in many industrial fields such as pharmaceuticals, OLEDs, carbon dioxide utilizations, dye-sensitizer solar cells and sensors. We expect that these products would be used for the development of further new industrial products.

\section{Keywords}

Cyclometalation, Catalyst, Five-Membered Ring, Chiral Reaction, Metathesis Reaction, Cross-Coupling Reaction

\section{Introduction}

When cyclometalation reactions are performed using metal compounds with substrates that contain heteroatoms 
with a strong donor ability, such as amines, phosphines, alcohols and sulfur compounds, the reactions show high reactivity of the substrate to the metal compounds because the compounds with these heteroatoms are usually used as catalysts. Therefore, various articles, many reviews [1]-[49] and books [50]-[55] on this subject have been published since the 1960s, and cyclometalation reactions are considered representative reactions in organic synthesis.

Commonly, cyclometalation reactions with conventional substrates that have a $\gamma$ carbon atom as the heteroatom proceed very easily via agnostic interactions with $\mathrm{CH}$ activation, as shown in Equation (1.1) [45]. Then, the metal atom is coordinated by the heteroatom and becomes the active center in the five-membered ring products. Many compounds easily afford their derivatives from reactions such as alkylation, alkenylation, alkynylation, carbonylation, isocyanation, halogenation, chiral reactions with amino acids, enantioselective rearrangement, asymmetric Diels-Alder reactions and dehydrogenation [41] [43] [55].

\section{Cyclometalation Reactions}
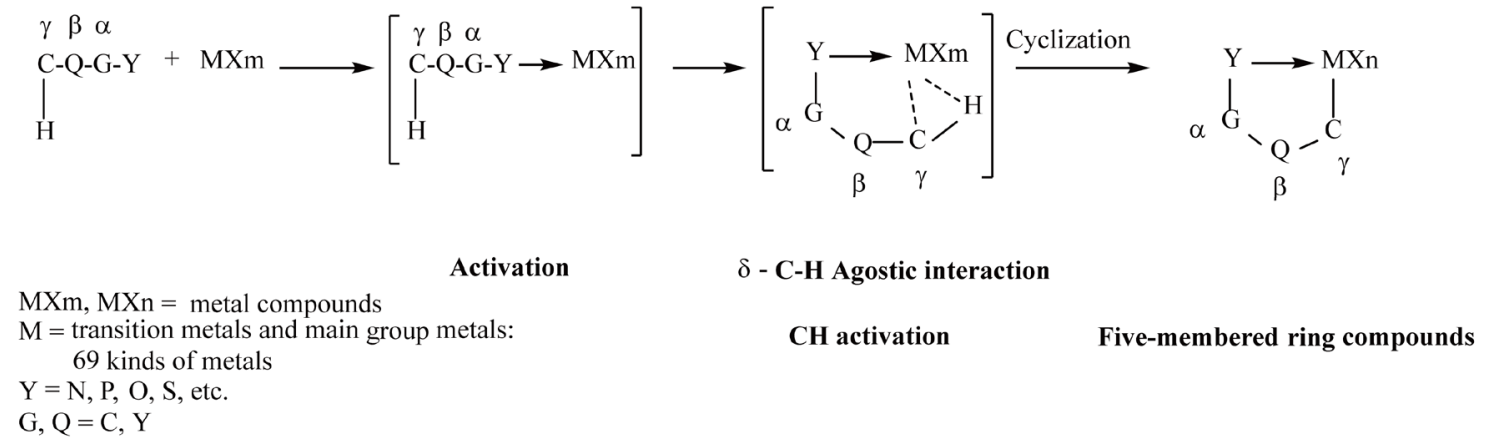

Ligands in cyclometalation reactions include atoms such as N, P, As, O and S. and groups such as alkenyl, allyl, alkynyl, aryl, cyclopentadienyl (Cp) and pentacyclopentadienyl (CP*). In the chelate compounds, fivemembered ring compounds are well known to be more stable than the comparable four- and six-membered ring compounds [56]. The ring products are coordinated with one of the above-mentioned ligand atoms in cyclometalation reactions are also generally known to be stable in organic ring compounds.

The products of the cyclometalation reactions are mainly four- to six-membered ring products. In particular, five-membered ring products are mostly synthesized in the cyclometalation reactions because five-membered ring compounds are the most stable type of rings [40] [41] [43] [55], and these products are very easily synthesized.

A monograph [55] was published to explain why organometallic intramolecular-coordination five-membered ring products are extremely easily synthesized through cyclometalation reactions, and three reasons were listed. First, activation of the metal is caused by coordination of a lone electron pair of a heteroatom to the metal atom. Second, the chelate effect is caused by the formation of a five-membered ring. Third, the metal is activated by ligands such as heteroatom-containing groups (e.g., bipyridnes, phosphines and carboxylates), unsaturated groups (e.g., aryl, allyl, $\mathrm{Cp}$ and $\mathrm{Cp} *$ ), carbonyl groups and halogen atoms ( $\mathrm{F}, \mathrm{Cl}, \mathrm{Br}$ and $\mathrm{Cl}$ ), which bond to a central metal atom. Many articles have been published with title words such as $\mathrm{C}-\mathrm{H}$ activation, $\mathrm{C}-\mathrm{X}$ activation, $\mathrm{C}-\mathrm{H}$ functionalization and chelation-assisted reactions which are related to the aforementioned metal activation and chelate effect in cyclometalation reactions [11] [13] [25] [26] [28] [30] [45] [55].

Among the other types of cyclometalation reaction, reactions with ligand groups [57]-[60] are compared with those with ligand atoms. However, there are few publications on this subject, and this article does not describe them.

In these cyclometalation reactions, the substrates and metal compounds are as follows:

1) Substrates with heteroatoms such as N [7] [15] [21] [32] [36], P [16]-[18] [20] [35], As [20] [37], O [12] [31] [34] [38] [44] and S [33].

2) Conventional substrates with a $\gamma$ carbon atom as the heteroatom to form five-membered ring products, as shown in Figure 1.

3) Unconventional base substrates such as 2-amino-3-picolines and anilines and auxiliary substrates such as alkynes and aldehydes [47]. 
<smiles>[R]N=C([R])c1ccccc1</smiles><smiles>CN(C)c1cccc2ccccc12</smiles><smiles>c1ccc(-c2ccccn2)cc1</smiles><smiles>c1ccc2c(c1)ccc1cccnc12</smiles><smiles>CC(C)C1C(F)=CC=C1CN(C)C</smiles><smiles>[R20]Cc1cccc(C[R20])c1</smiles><smiles>[R]N=Cc1cccc(C=N[R])c1</smiles><smiles>[R]C=C([R])C([R])=O</smiles><smiles>[R]CC([R])C[R]</smiles><smiles>[R]C=C([R])C[R18]</smiles><smiles>CCCCN(C)C</smiles><smiles>[R]N=CCC[Tl]</smiles><smiles>[R]OCCCC</smiles><smiles>[R12]CCCC</smiles><smiles>[R]OC(=O)CCI</smiles>

Figure 1. Representative conventional substrates to synthesize five-membered ring compounds in cyclometalation reactions [55]. Asterisks $(*)$ indicate the reaction sites of the metal compounds. There are generally at the $\gamma$ position to a coordinating atom such as $\mathrm{N}, \mathrm{P}, \mathrm{O}$ or $\mathrm{S}$.

4) Ancillary ligands such as 2,2'-bipyridines, terpyridines and 1,10-phenanthroline in some cyclometalation reactions, which chelate with metal compounds.

5) Transition metal and main group metals in general. In total, of 69 types of metal atoms are used [44] [55].

6) Various types of metal compounds.

Accordingly, various five-membered products of cyclometalation reactions are synthesized with all types of combinations of substrates with heteroatoms, conventional substrates, unconventional substrates, ancillary ligands, metal atoms and metal compounds.

Therefore, many articles on the five-membered ring products of cyclometalation reactions have been published. These metal compounds, which are coordinated by a heteroatom and many ligand groups are used as catalysts [41] [43] [55] and in the fields of OLED [48], pharmaceuticals [46], $\mathrm{CO}_{2}$ utilization [49], dye-sensitizer solar cells [55], sensors, etc. [55].

This article describes three types of catalytic actions of the five-membered ring products of cyclometalation reactions [41] [43] [47] [55].

1) Use of stable five-membered ring products of cyclometalation reactions as catalysts [41] [43] [55].

2) Use of the catalytic action of the reactive five-membered ring intermediates of cyclometalation reactions. Conventional substrates are used [41] [43] [55].

3) Use of the catalytic action of the reactive five-membered ring intermediates of cyclometalation reactions. However, unconventional substrates of the base substrates and auxiliary substrates are used [47].

Furthermore, recent articles on the first and second types of catalytic actions of the five-membered ring products of cyclometalation reactions are also described. 


\section{Three Types of Applications of Cyclometalation Five-Membered Ring Products and Intermediates as Catalytic Agents}

\subsection{Introduction}

Many five-membered ring products of cyclometalation reactions have been synthesized because the reactions proceed very easily with many types of metal compounds, substrates and ancillary ligands. The five-membered ring products have many functions: they can be used as catalytic agents and in the fields of OLED, pharmaceuticals, $\mathrm{CO}_{2}$ utilization compounds, dye-sensitized solar cells and sensors, as previously described.

This article describes three types of catalytic agents from the five-membered ring products of cyclometalation reactions.

1) Use of the five-membered ring products of cyclometalation reactions as catalysts because of their catalytic activity and high stability.

2) Use of the catalytic agents of the reactive five-membered ring intermediates of cyclometalation reactions as catalytic agents. In general, the final reaction products are the derivatives of the conventional substrates, which have a $\gamma$-carbon atom as the heteroatom in the substrates.

3) Use of the catalytic action of the reactive five-membered ring intermediates in cyclometalation reactions. These substrates are unconventional base substrates and auxiliary substrates [47].

\subsection{Applications of Cyclometalation Five-Membered Ring Products as Catalysts}

Several catalytic reactions that involve the five-membered ring products of cyclometalation reactions as catalysts have been reported in reviews [41] [43] and a monograph [55].

Recently three Nobel prizes in synthetic organic reactions were awarded for chiral reactions in 2001, metathesis reactions in 2005 and cross-coupling reactions in 2010. This chapter briefly describes these chiral, metathesis, cross-coupling reactions and other reactions such as polymerizations, reductions and dehydrogenations.

In chiral reactions with the five-membered ring products of cyclometalation reactions, the metal atoms in the metal compounds act as the catalysts, and the Pd atom is mainly used as the catalyst. Many reviews report that palladium compounds serve as chiral catalysts [61]-[67]. The other metal atoms are Pt, Rh and Ru. Other articles have been published on other catalytic metal compounds such as Fe, Au, Ir, Sc, Y and Lu [68]-[71].

For the heteroatoms, a stronger donor $\mathrm{N}$ atom is mainly used, and other heteroatoms include $\mathrm{P}, \mathrm{O}$ and $\mathrm{S}$.

Some examples of palladium catalysts for chiral reactions are shown in Figure 2 [61] [62] [72] [73].

In 1980, Noyori et al. [72] reported the synthesis of BINAP (2,2'-bis(diphenylphosphino)-1,1'-binaphtyl), which shows high enantioselectivity and catalytic activity as a super-chiral ligand of a chiral N,N-dimethylamine palladium compound 2.2, as shown in Scheme 1.<smiles>C[C@H](N)c1c(P)ccc2ccccc12</smiles>

2.1<smiles>C[C@@H]1c2ccccc2[C@@H](C)N1C</smiles><smiles>[R16]</smiles>

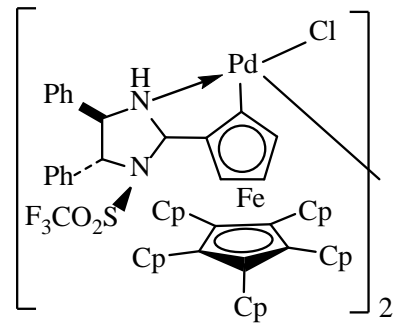

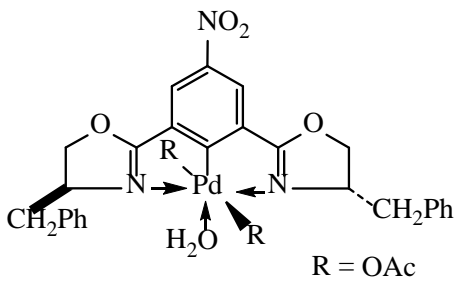




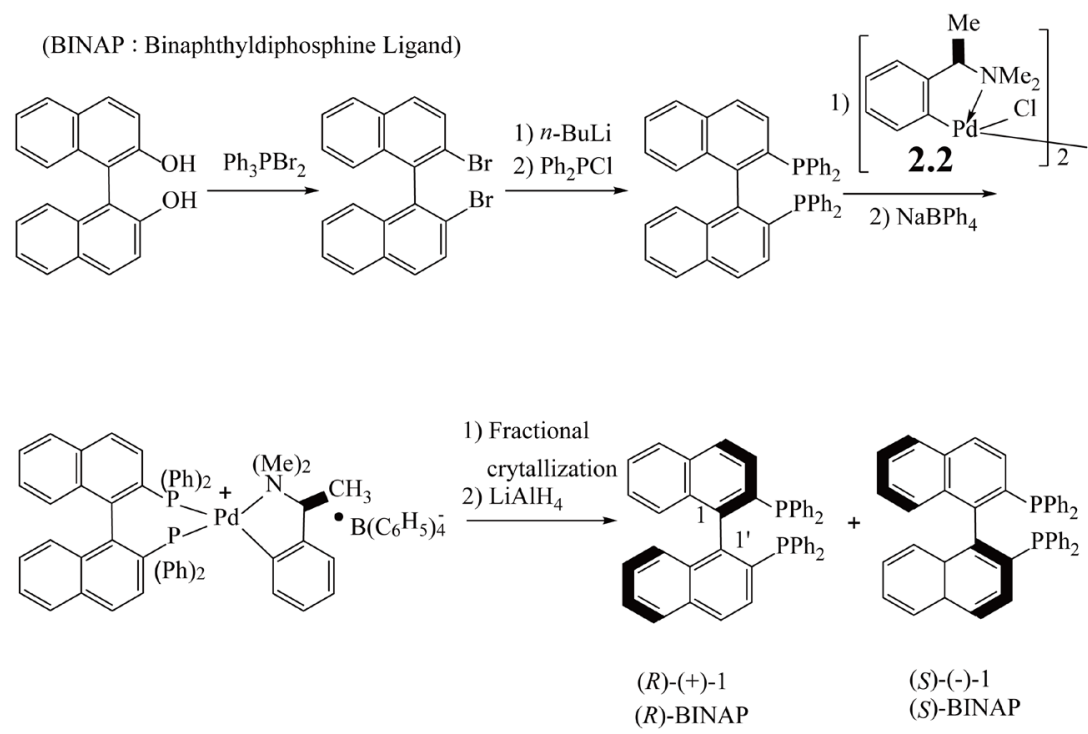

Scheme 1. Preparation of BINAP [72].

For chiral reactions, two examples of five-membered ring products of cyclometalation reactions for rearrangements and Michael addition reactions are shown in Equations (2.2.1) and (2.2.2).

Moreover, with a cyclopalladate ( $\eta^{4}$-tetraphenylcyclobutadiene)cobalt oxazoline propyl chloro-bridged compound 2.5 as a catalyst, the rearrangements of $N$-(4-methoxyphenyl)trifluoroacetimidate 2.6 [74], to the corresponding amides 2.7 proceed with high yields and high enantiomeric purities without using a silver salt as an activator, as shown in Equation (2.2.1).

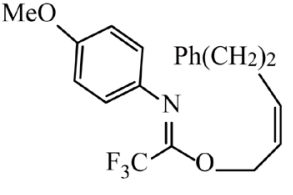

2.6
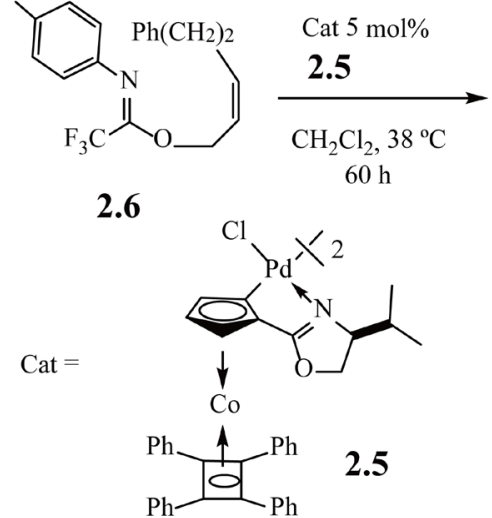<smiles>C=CC(CCCCCCCCCCCCCCCC)N(C(=O)C(F)(F)F)c1ccc(OC)cc1</smiles>

2.7

Yield 99\%

$96 \%$ ee $(R)$

Pincer metal compounds such as those with tin [75], rhodium [76], palladium [77] and platinum [78], are used as catalysts for Michael addition reactions. For example, the addition of an $\alpha$-cyanopropionate to acrolein under mild, neutral conditions in the presence of a bis(oxazolinyl)phenylstannane-derived rhodium complex $\mathbf{2 . 8}$ enantioselectively proceeds with high yield and high TON, as shown in Equation (2.2.2) [76].

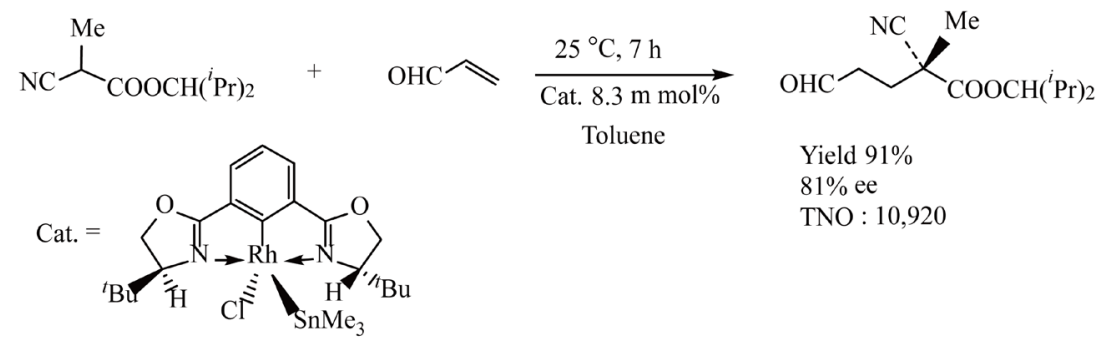


Metathesis reactions were reported in some reviews [79]-[84] and a handbook [85]. There are notably fewer types of metal atoms in metathesis reactions than in chiral reactions. Mainly Mo, W, Ta and Ru are used for this types of reactions.

The ruthenium-carbene complex 2.9 is an excellent commercially available example of Grubbs' catalyst. However, cyclometalation five-membered ring products $1_{\mathrm{st}}$ and $2_{\text {nd }}$-generation Hoveyda-Grubbs catalysts 2.10 - 2.12 which are activated by coordination with an ether oxygen atom, are much more active with respect to electron-deficient olefins and stable with respect to air as shown in Figure 3 [55] [81] [82] [86].<smiles>Cl[Te](Cl)(Cl)(Cl)(Cl)c1ccccc1</smiles>

2.9

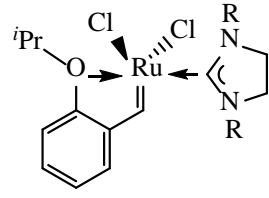

2.10

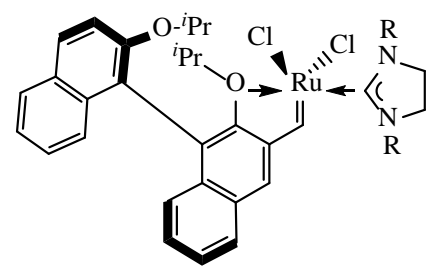

2.11<smiles>[R]C=CC(C)C</smiles>

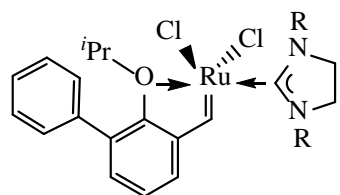

2.12

Figure 3. Representative metathesis reaction catalysts.

Many ruthenium carbene five-membered ring compounds have recently been reported to show good activities for metathesis. Many types of reactions proceed with the help of these catalysts, such as ring-closing metathesis, ring-opening metathesis, cross metathesis, enyne metathesis and diyne metathesis [55] [81].

For example, the ring-closing metathesis of an acyclic diene easily proceeds at room temperature with a high yield in the presence of the 1,3-dimesityl-4,5-dihydroimidazole-2-ylidene ruthenium catalyst 2.10, as shown in Equation (2.2.3) [86] [87].<smiles>C=CCN(C)C(=O)C(=C)C</smiles>

Ts $=$ tosyl,$p$-toluenesulfonyl

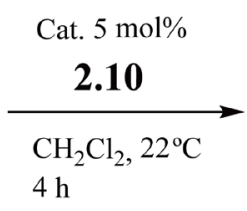

$$
\text { (1) }
$$

Many cross-coupling reactions have been reported si

These reactions include Heck reactions, Mizoroki-Heck reactions, Negishi reactions and Suzuki-Miyaura reactions.

Among these reactions, three were recognized with a Nobel Prize in Chemistry in 2010. The Nobel Prize was awarded based on practical use in the industrial sector. Heck reactions were used to synthesize of more than 100 types of natural products and physiologically active substances, Negishi reactions were used to synthesize Pumiliotoxins A (PTXs) and Hennoxazole A. Suzuki-Miyaura reactions were used to synthesize Dynemicin A and Dragmacidine F [88].

Various articles and many reports [89]-[94] have been published on cross-coupling reactions using the fivemembered ring compounds of cyclometalation reactions as catalysts:

Palladium compounds are mainly used as catalysts, but $\mathrm{Ni}$, Ir, Ru and Pt compounds are also used.

In particular, many Heck and Suzuki-Miyaura reactions have been reported for the five-membered ring products of cyclometalation reactions.

Some examples are shown bellow: 


\section{Moritani-Fujiwara reaction}

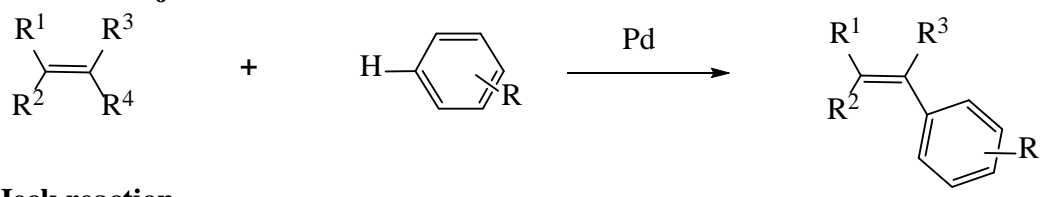

1967

Heck reaction

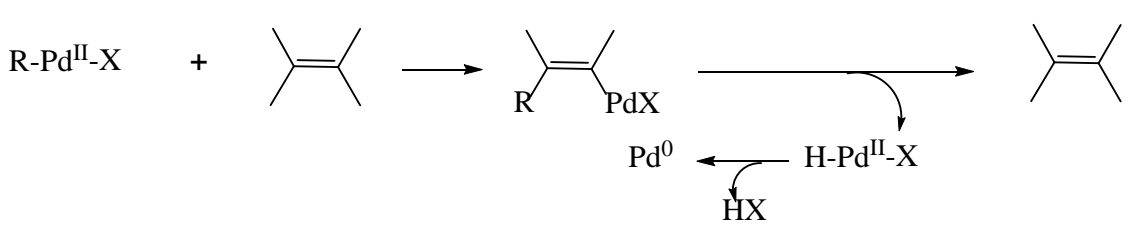

Mizoroki-Heck reaction<smiles>[R][X][Na]</smiles><smiles>[R16][R16]([H])([H])C</smiles><smiles>[R]C([Y])=C([R])[Hg]</smiles>

Negishi reaction

$$
\begin{aligned}
& \mathrm{R}^{1}-\mathrm{Zn}-\mathrm{X}+\mathrm{R}^{2}-\mathrm{X} \\
& \left(\begin{array}{l}
\mathrm{R}^{1}-\mathrm{Al}-\mathrm{X} \\
\mathrm{R}^{1}-\mathrm{Zr}-\mathrm{X}
\end{array}\right)
\end{aligned}
$$

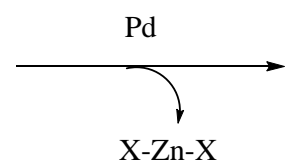

$\mathrm{R}^{1}-\mathrm{R}^{2}$

\section{Suzuki-Miyaura reaction}

$\mathrm{R}^{1}-\mathrm{B}-\mathrm{R}^{3}+\mathrm{R}^{2}-\mathrm{X}$

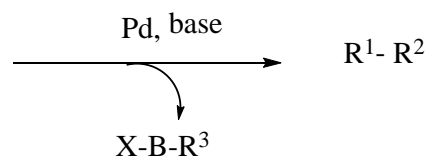

1979

\section{Figure 4. Cross-coupling reactions [88].}

In 2005, Heck reactions with phospha-palldacycles [95] or $N$-heterocyclic carbene phospha-palladacycles [96] were reported to show highly catalytic activities, as evidenced by their TONs of up to 300,000 and 533,000, respectively.

Among the Suzuki reactions, palladacycle catalysts exhibit very high TONs. Most notably, phosphite palladacycles 2.13 show the highest TON of $10^{6}$ [97]-[100].

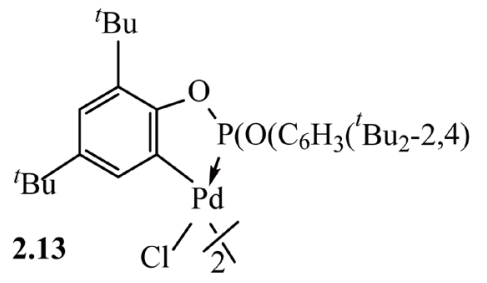

For other reactions, this section shows two examples of polymerizations and reductions.

Among the polymerization catalysts, Ziegler catalysts $\left(\mathrm{Et}_{3} \mathrm{Al}\right.$ and $\left.\mathrm{TiCl}_{4}\right)$, Natta catalysts $\left(\mathrm{Et}_{3} \mathrm{Al}\right.$ and $\left.\mathrm{TiCl}_{3}\right)$, and metallocene catalysts $\left(\mathrm{Cp}_{2} \mathrm{M}(\mathrm{M}=\mathrm{Ti}, \mathrm{Zr}, \mathrm{Hf}, \mathrm{Fe})\right)$ and $\left.-(\mathrm{O}-\mathrm{Al}(\mathrm{R}))_{\mathrm{n}^{-}}(\mathrm{R}=\mathrm{Me}, \mathrm{Et})\right)$ are used as vinyl polymerization catalysts. $\mathrm{Ca}, \mathrm{Hg}, \mathrm{Zn}$ and $\mathrm{Cd}$ compounds and $\mathrm{Ti}, \mathrm{Ge}, \mathrm{Sn}, \mathrm{Pb}$ and $\mathrm{Sb}$ compounds are used for ester exchange and their polyester polymerization catalysts, respectively.

However, organometallic intramolecular-coordination five-membered ring compounds have also recently been used as polymerization catalysts.

The polymerization reactions of compounds such as ethylene polymerization, ethylene/1-octene and propylene polymerization and isoprene polymerization reactions and their catalysts of cyclomelated products are 
shown in Figure 5 [101]-[103].

For example emine-type cyclopalladated products $\mathbf{2 . 1 4}$ have good activity for ethylene polymerization [101]. The molecular weight and molecular weight distribution of the obtained polymers correspond to single-site catalysts, and the polymers have narrow molecular weight distribution, as shown in Table 1.

Pincer organometallic compounds are reported mainly with regard to two types of compounds, NCN and PCP transition-metal complexes [63] [91]. However, ruthenium pincer CNN compounds have also been applied to the hydrogen-transfer reductions of ketones.

For example, 6-(4'-methylphenyl)-2-pyridylmethylamine ruthenium pincer compound $\mathbf{2 . 1 7}$ is a highly efficient catalysts in transfer hydrogenation, which involves 2-propanol, quantitatively reduce ketone with notably low loading in a short time, as shown in Equation (2.2.4) [104].

Ethylene polymeriation<smiles></smiles>

2.14

$\mathrm{R}^{1}, \mathrm{R}^{2}$

[101]

a $\mathrm{H}, \mathrm{H}$

b Me, $\mathrm{H}$

c Me, Me

$\square$ shows the generation of the $d$ orbital vacancy of palladium in the complexes.
Etylene/1-octene and propylene polymerization

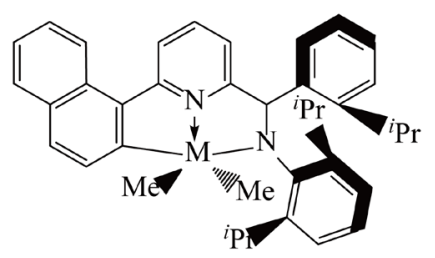

$\mathrm{M}=\mathrm{Hf}, \mathrm{Zr}$

2.15

Isoprene polymerization

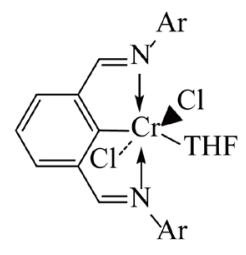

2.16

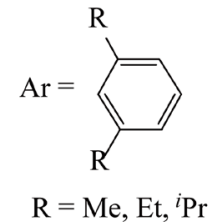

$\mathrm{R}=\mathrm{Me}, \mathrm{Et},{ }^{i} \mathrm{Pr}$

[103]

Figure 5. Polymerization reactions and their catalysts with cyclometalated products.<smiles>CC(=O)c1cccc(Cl)c1</smiles>

$$
\begin{aligned}
& \frac{82{ }^{\circ} \mathrm{C}}{\text { Cat. } 0.005 \mathrm{~mol} \%} \\
& \mathrm{NaOH}(2 \mathrm{~mol} \%) \text {, }
\end{aligned}
$$

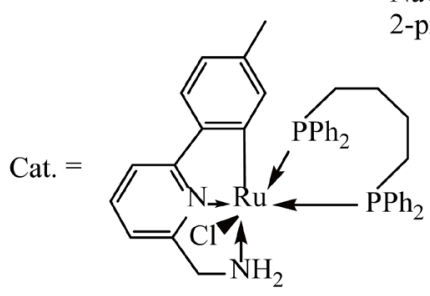<smiles>CC(O)c1cccc(Cl)c1</smiles>

Coversion 99\%

TOF: $2.5 \times 10^{6} \mathrm{~h}^{-1}$

\subsection{7}


Table 1. Molecular weight, molecular weight distribution and melting temperature (Tm) of polyethylene obtained using the imine cyclometalated palladium catalysts $\mathbf{2 . 1 4 b}$ and $\mathbf{2 . 1 4 c}$ [101].

\begin{tabular}{ccccc}
\hline Catalyst & Reaction temp. $\left({ }^{\circ} \mathrm{C}\right)$ & $\operatorname{Tm}\left({ }^{\circ} \mathrm{C}\right)$ & $M \mathrm{w}$ & $\mathrm{Mw} / \mathrm{Mn}$ \\
\hline $\mathbf{2 . 1 4 b}$ & 80 & 136 & 74,000 & 1.7 \\
$\mathbf{2 . 1 4 c}$ & 40 & 137 & 245,000 & 2.1 \\
\hline
\end{tabular}

\subsection{Applications of Cyclometalation Five-Membered Ring Intermediates as Catalytic Agents}

The second type of catalytic agent has weak coordination to the metal compounds and the catalysts are highly reactive intermediates of the five-membered ring cyclometalation reactions [105]. In particular, Murai et al. have published reports on such catalytic actions with ruthenium compounds since 1993 [106]-[116]. In this type of catalytic agents, the ligands mainly use the relatively weak donation of the oxygen atoms of ketone carbonyl, ester carbonyl, aldehyde carbonyl and amide carbonyl groups and the nitrogen atoms of oxazole, amide, imine and azo groups, whereas $\mathrm{Ru}, \mathrm{Rh}, \mathrm{Co}, \mathrm{Zr}$ and $\mathrm{Pd}$ compounds are mainly used as the metal compounds.

For example, the alkenylation reaction with a phenyl ester as a substrate proceeds via cyclometalation with intermediate $\mathbf{2 . 1 8}$ to produce an alkenyl derivative in high yield, as shown in Equation (2.3.1) [117].

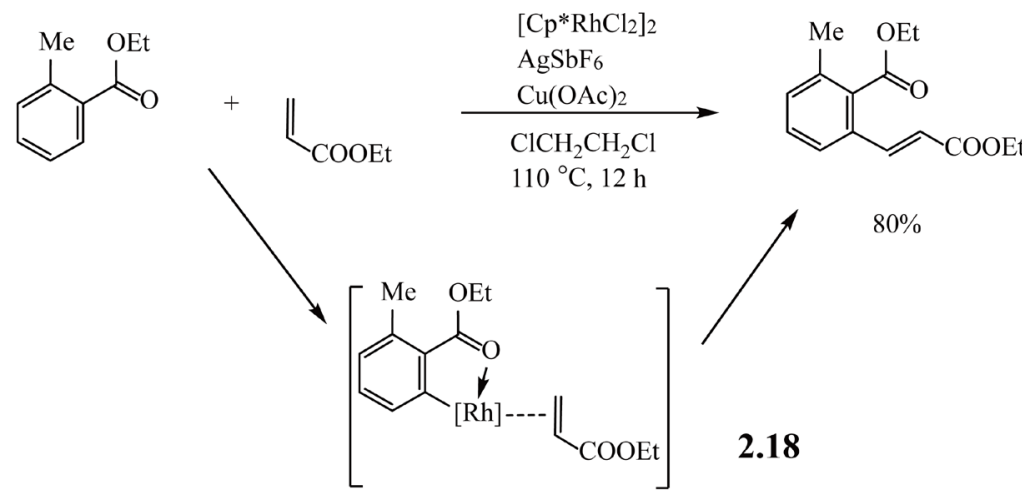

Cyclopalladated t-butylimine compounds react with styrene and are consequently treated with trifluoroacetic acid to produce $o$-formylstilbenes in high yield. Their $N$-methylimine derivatives are converted to other heterocyclic compounds (3-aryl- $N$-methyl-isoquinolones 2.19) by oxidation with mercuric acetate, as shown in Equation (2.3.2) [118].
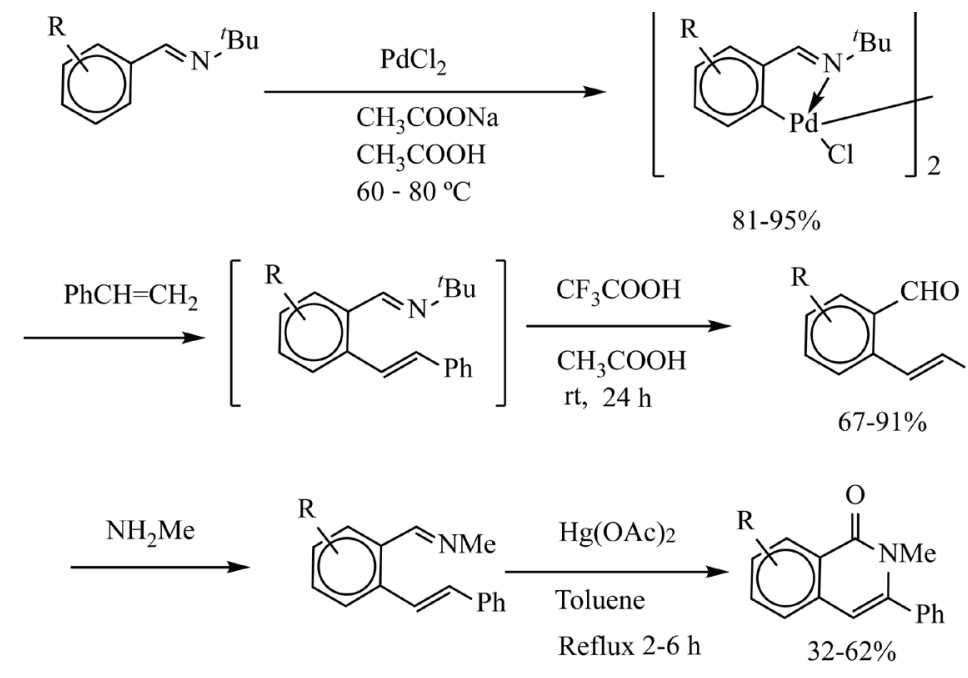

$\mathrm{R}=\mathrm{H}, 5-\mathrm{Cl}, 3-\mathrm{MeO}, 4-\mathrm{MeO}, 5-\mathrm{MeO}, 4,5-(\mathrm{MeO})_{2}$ 
Other reactions such as alkylation, alkynylation, arylation, carbonylation, hydroacylation, ring-expansion reaction, carbocyclization, cross-coupling reaction, reductive elimination, carbonylation and hydroacyclation have also been reported [41] [43] [55].

\subsection{Applications of Cyclometalation Five-Membered Ring Intermediates with Unconventional Substrates as Catalytic Agents}

The third type includes reactions that using base substrates such as 2-amino-3-picoline and anilines which do not have a $\gamma$-carbon atom as the hetero atom, and auxiliary substrates such as aldehydes and alkynes. This reaction produces conventional substrates, and the reactions with metal compounds produced the reactive five-membered ring intermediates from cyclometalation reactions. Finally, the derivatives of the reactive five-membered ring intermediates are formed as shown in Equation (2.4.1) and Scheme 2 [119].

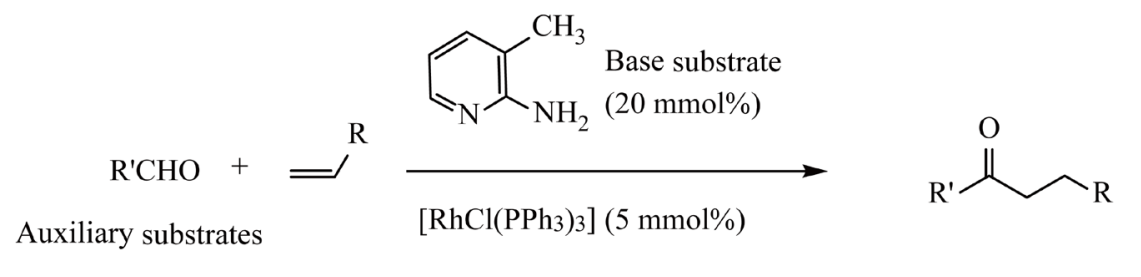

$$
\begin{aligned}
& \mathrm{R}=n-\mathrm{Bu}, n-\mathrm{Pr}, t-\mathrm{Bu}, \mathrm{PhCH}_{2^{-}}, \mathrm{C}_{6} \mathrm{~F}_{5^{-}}, \text {etc. } \\
& \mathrm{R}^{\prime}=\mathrm{Ph}, \mathrm{C}_{6} \mathrm{H}_{5}-\mathrm{OMe}-p, \mathrm{C}_{6} \mathrm{H}_{5}-\mathrm{CH}_{2} \mathrm{CH}_{2^{-}}, \text {Cyclohexyl }
\end{aligned}
$$

Yield: $49-92 \%$

In metal compounds, such as $\mathrm{Mn}, \mathrm{Pd}, \mathrm{Rh}$ and Ir compounds, the cyclization reactions of unsaturated compounds, such as alkynes, alkenes and phenyl compounds proceed via cyclocarbonylation based on the following four characteristics [47].

1) Carbon-carbon $\pi$-electrons in these unsaturated compounds easily form $\pi$-coordination bonds to the metal atom.

2) In the metal carbonyl compounds, hydrogen or an organic group easily migrates to a carbonyl.

3) The coupling reactions between a carbonyl carbon in the metal carbonyl compounds and a carbon atom in

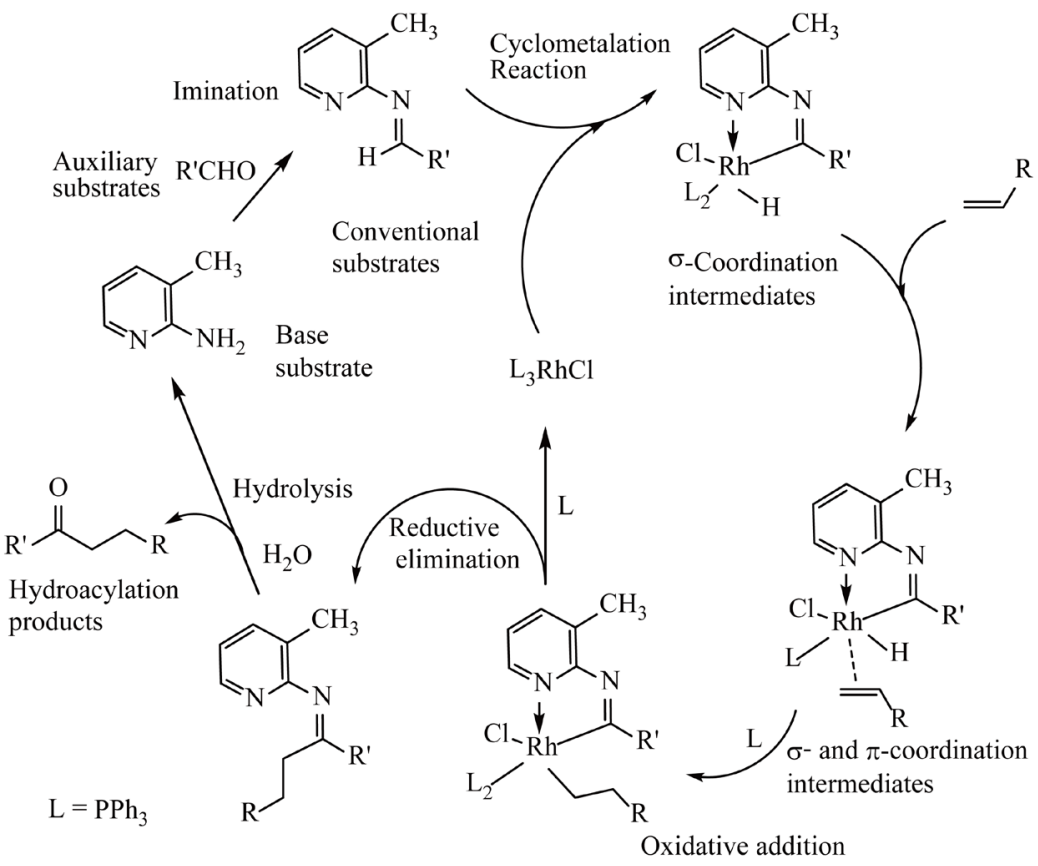

Scheme 2. Proposed mechanism for hydroacylation via cyclometalation reactions [119]. 
the unsaturated $\pi$-coordination bonds easily proceed.

4) Five-membered ring compounds are easily formed by the $\sigma$-coordination of the carbonyl oxygen atom to the metal atom.

These characteristics of metal carbonyl compounds and unsaturated hydrocarbons enable the cyclometalation reactions of these compounds to easily proceed without using conventional substrates.

For example, Stone et al. [120] reported the unconventional cyclometalation reaction of a manganese carbonyl with an alkyne as shown in Equation (2.4.2).

First, the unsaturated $\pi$-electrons of the alkyne coordinate to the manganese atom with the concomitant migration of a hydrogen atom from the manganese to a carbonyl group.

The coupling reaction between a carbonyl carbon atom and hydrogen occurs via the migration reaction, where the alkyne carbon atom bonds with an electron attractive trifluoromethyl group. Finally, cyclization reactions occur in the form of cyclocarbonylation, which is caused by the coordination of the carbonyl oxygen atom to the manganese atom.

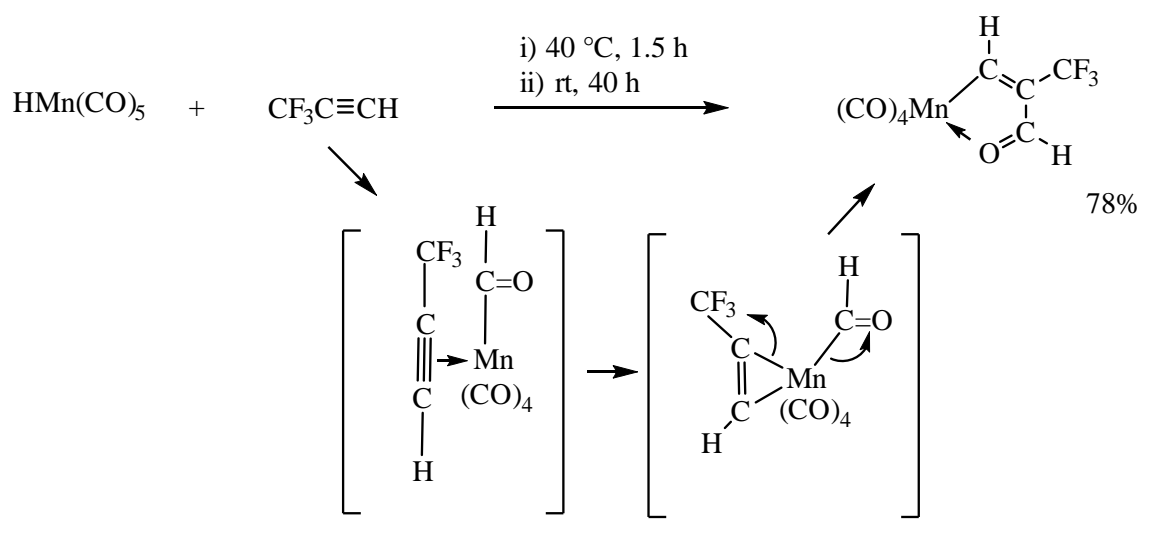

Alkynes or alkenes react with alkylmanganese carbonyl compounds at high pressures (2 - $10 \mathrm{kbar}$ ) to provide the five-membered ring products $\mathbf{2 . 2 0}$ and 2.21via the coupling reactions of the organyl migration carbonyl moiety with alkynyl or alkenyl groups in good yields. These cyclometalated products are used as intermediates to prepare organic compounds [121].

For example, alkyne cyclometalated intermediates 2.20 afford $E$-enones 2.23 under acidic conditions by demetalation. Alternatively, the intermediates 2.20 afford butenolides 2.24 via an intramolecular Reppe reaction by hydride reduction. Finally, alkene cyclometalated intermediates 2.21 afford ketones 2.25 by photochemical demetalation as shown in Scheme 3 [121].

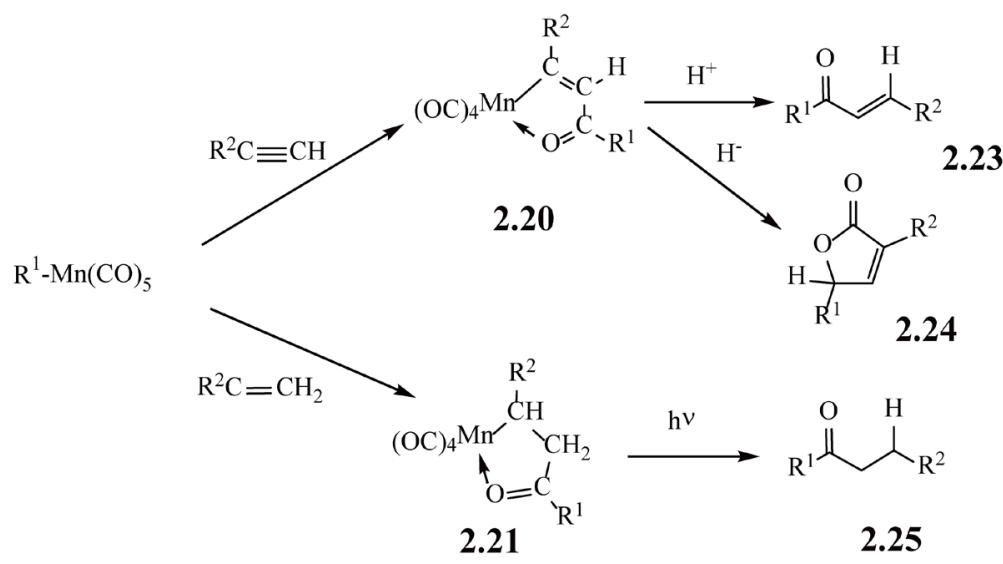

Scheme 3. A variety of alkylmanganese pentacarbonyl compounds regioselectively react with structurally diverse alkynes or alkenes to produce their cyclometalated intermediates [121]. 


\section{Recent Applications of Cyclometalation Five-Membered Ring Products and Intermediates as Catalytic Agents}

\subsection{Introduction}

The author has published a review article on the applications of cyclometalation five-membered ring (intermediate) products with catalytic actions [41] [43] [55]. Thus, this chapter only describes very recent cyclometalation five-membered ring products as catalysts and cyclometalation five-membered ring intermediates with catalytic actions.

\subsection{Recent Applications of Cyclometalation Five-Membered Ring Products as Catalysts}

Recently, the main metal compounds of the five-membered ring products of cyclometalation reactions, which are used as catalysts in the chiral reactions, are Pd compounds, and the other metal compounds are Pt, Ir, Rh, Ru and Fe compounds [122]-[130].

For examples, the asymmetric hydroarsination reaction [131], hydrogenation [132] and asymmetric azaMichael reaction are cited [133].

An asymmetric hydroarsination reaction between diphenylarsine and 3-diphenylphosphanyl-but-3-en-1-ol has been achieved using ortho-metalated $(R)$-[1-dimethylamino)ethenylnaphthalene as the chiral reaction template 3.1 with high stereoselectivity under mild reaction conditions, as shown in Scheme 4 [131]. The hydroarsination of 3-diphenylphosphanyl-but-3-en-1-ol with diphenylarsine produces only one stereoisomer as a five-membered As-P bidentate chelate on the chiral naphthylamine palladium template 3.2. The naphthylamine auxiliary can be chemoselectively removed by treatment with concentrated hydrochloric acid. The absolute configuration of the final hydroarsination product has been established using single crystal X-ray analysis.

The following chiral reactions of phenyl alkyl ketone were reported for hydrogenation in the presence of bis(oxazolinyl)phenyl metal compounds 3.3, as shown in Equation (3.2.1) [132]. Furthermore, for the latter bis(oxazolinyl)phenyl ruthenium catalyst 3.3, Ito, J., Teshima, T. and Nishiyama, H. [132] reported, a significant increase in enantioselectivity with a zinc-chloride-bridged ruthenium compound.

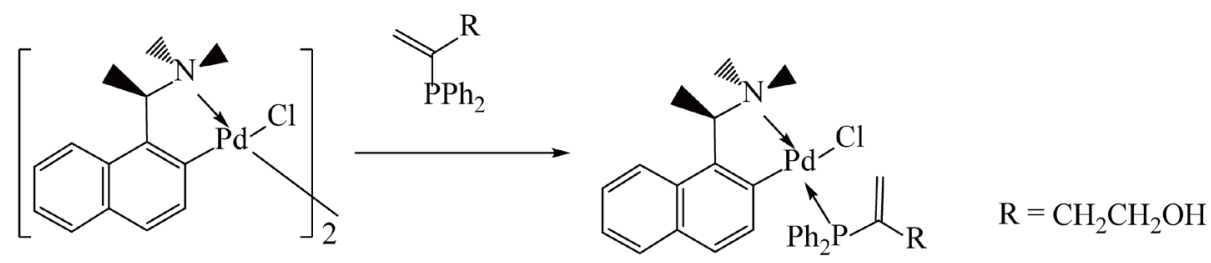

$(R c)$

3.1

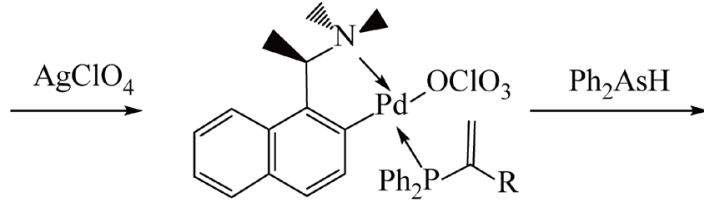

$(R c)$

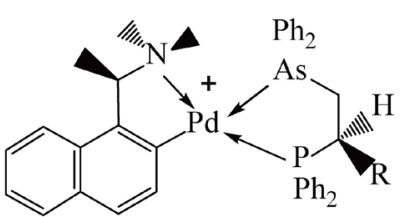

3.2

$(R c, R c)$

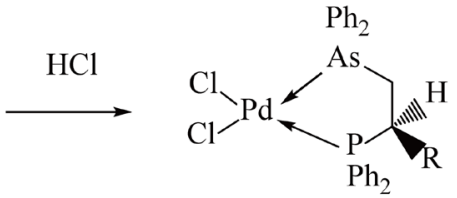

(Rc)

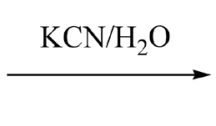

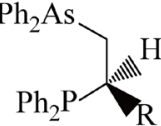

(Rc)

Scheme 4. Asymmetric hydroarsination reaction between diphenylarsine and 3-diphenlphosphanylbu-3-en-1-ol with ortho-metalated $(R)$-[1-dimethylamino]ethenylnaphthalene as the chiral reaction template [131]. 
<smiles>CC(=O)c1ccc(-c2ccccc2)cc1</smiles>

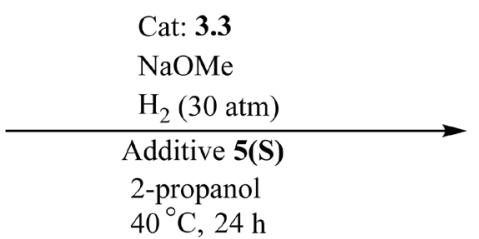<smiles>C[C@@H](O)c1ccc(-c2ccccc2)cc1</smiles>

$99 \%, 93 \%$ ee $(S)$

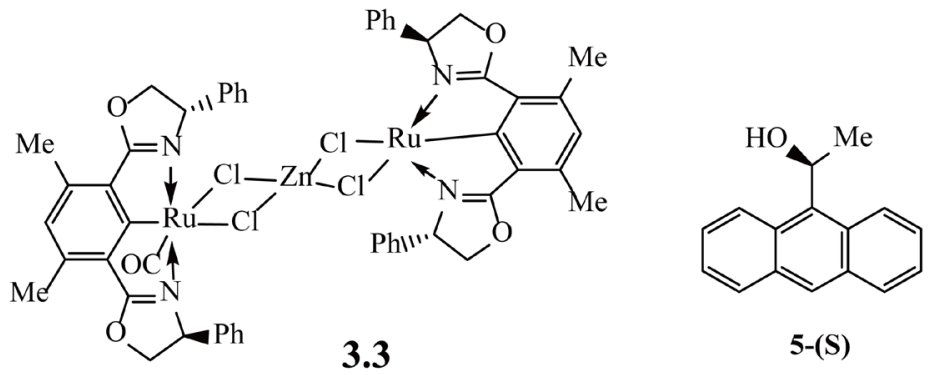

W. Zhang et al. [133] attempted the asymmetric aza-Michael addition of $\alpha, \beta$-unsaturated nitriles using the P-stereogenic Ni compounds of common five-membered ring 3.4 and 3.5 (Ni PCP) compounds and chelate type 3.6, 3.7 and 3.8 (Ni PNP) compounds. The reactions with the common Ni PCP pincer 3.4 and 3.5 compounds show much higher yields and higher ee\% than the reactions with the chelate type $\mathbf{3 . 6}$ - 3.8 Ni PNP pincer compounds as shown in Equation (3.2.2) and Table 2.<smiles>C=C(C#N)C(=N)c1ccccc1</smiles>

$\mathrm{X}: \quad \mathrm{Cl}$ OTf $3.4 \quad 3.5$

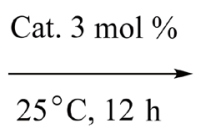<smiles>CC(C#N)CN1CCOCC1</smiles>

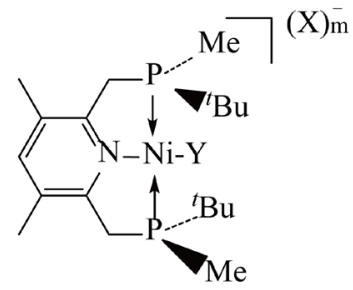

In Chapter 2, many metathesis reactions are shown with a Hoveyda-Grubbs metathesis catalyst, which has an oxygen donor atom as shown in Figure 3.

Recently, other catalysts have used nitrogen atoms as the heteroatoms:

Table 2. Reaction conditions of aza-Michael addition.

\begin{tabular}{cccc}
\hline Cat & Additive & Yield (\%) & ee (\%) \\
\hline 3.4 & AgOTf & 83 & 35 \\
3.5 & & 85 & 28 \\
3.6 & AgOTf & nd & \\
3.7 & AgOTf & 9 & 8 \\
3.8 & AgOTf & 11 & 11
\end{tabular}


The reaction of the Grubbs’ 3rd-generation complex (1,3-bis(2,6-diisopropylimidazolin)-2-ylidene complex) with 2-ethenyl-N-methylaniline forms complex 3.9. Compared to the conventional $O$-Grubbs-Hoveyda complex (such as 2.9 -2.12 in Figure 3), the new complexes are characterized by fast catalyst activation, which translates into fast and efficient ring-closing metathesis reactivity. Catalyst loadings of $15-150$ ppm (0.0015 - 0.015 mol\%) are sufficient to convert a wide range of diolefinic substrates into the respective ring-closing metathesis products after $15 \mathrm{~min}$ at $50^{\circ} \mathrm{C}$ in toluene as shown in Equation (3.2.3). The use of complex 3.9 in ring-closing metathesis reactions enables the formation of N-protected 2,5-hydropyrroles with turnover numbers (TONs) of up to 58,000 and turnover frequencies (TOFs) of up to $232,000 \mathrm{~h}^{-1}$ [134].

Ring-closing metathesis

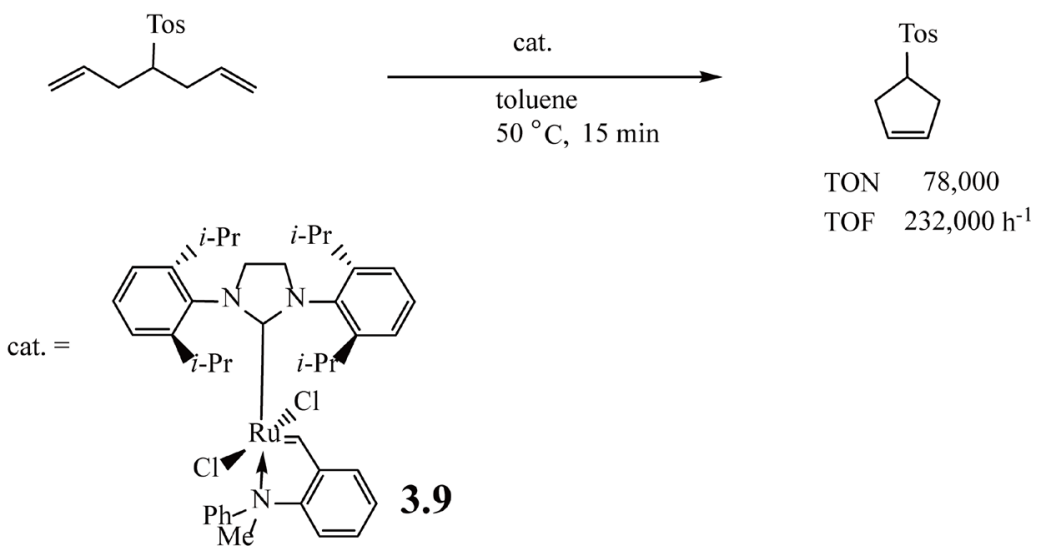

Recently, many cross-coupling reactions using cyclometalation reaction five-membered ring products as catalysts for Heck-type, Mizoroki-Heck and Suzuki cross-coupling reactions were reported, as shown in Figure 6.

Recently, the five-membered ring products of cyclometalation reactions for polymerization catalysts were reported as shown in Figure 7.

\section{Heck-type reactions}

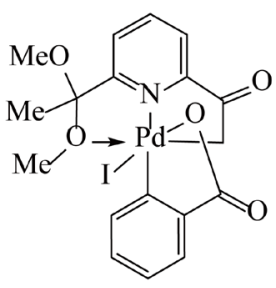

3.10

Suzuki cross-coupling reactions

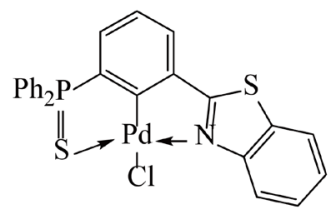

3.12
Mizoroki-Heck reactions

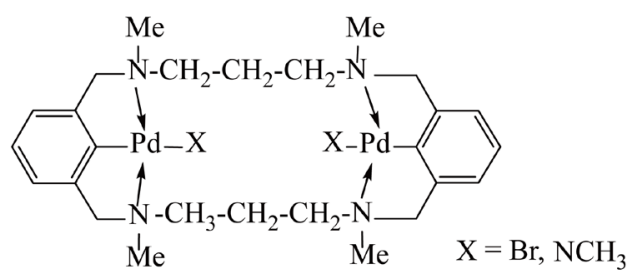

\subsection{1}

Suzuki cross-coupling reactions

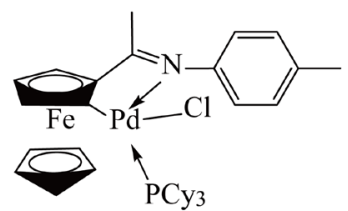

3.13

Figure 6. Recent cross-coupling reactions with cyclometalated five-membered products as catalysts for Heck type, Mizoroki-Heck, and Suzuki cross-coupling reactions. 
Ethylene polymeriation

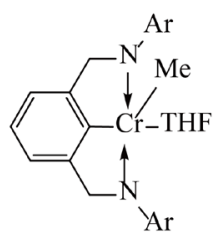

3.14

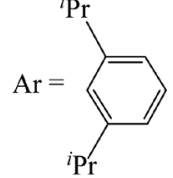

\subsection{5}

Olefin polymeriation

(1-Hexene, propylene, ethylene/1-octene) 

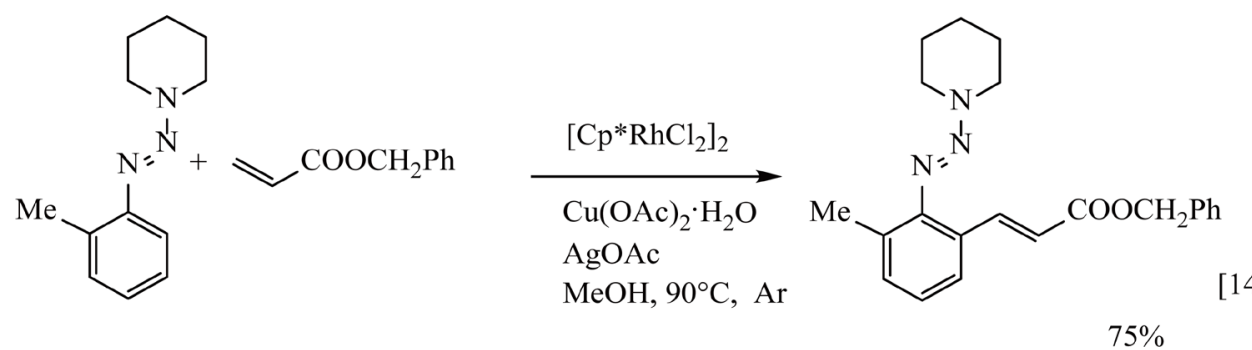

Alkynylations have been shown as reactions of cyclometalation reaction products with alkynes.

For example, a phenyimine as an arylimine reacts with an alkyne in the presence of a renium compound to give the cyclization product aminoindane $\mathbf{3 . 1 8}$ via a cyclometalation intermediate 3.17 , which is coordinated by an alkyne, as shown in Equation (3.3.4) [147].

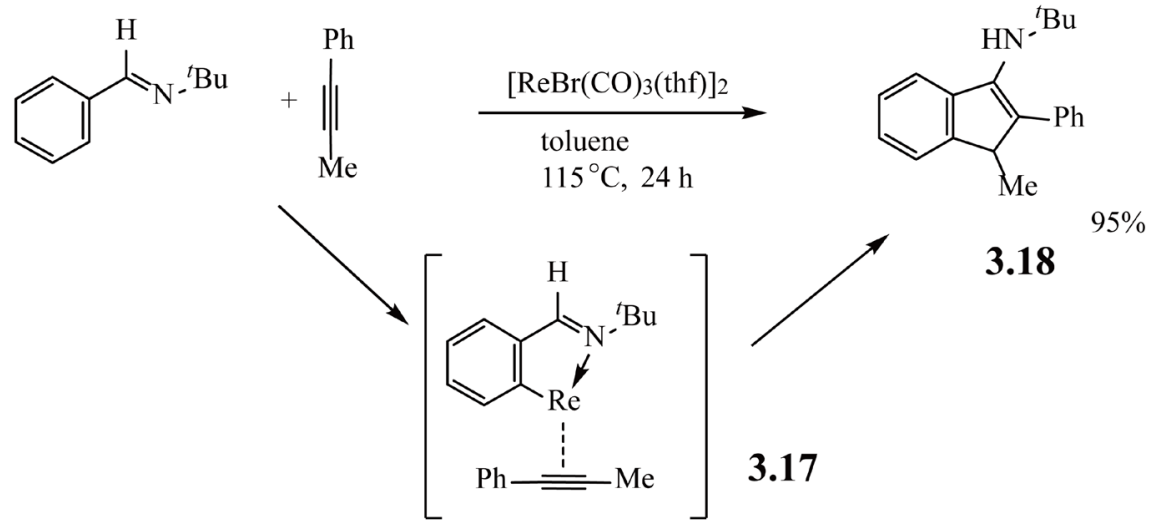

Other reactions are acylation [148], amination [149], halogenation [150] and silylation [151], as shown in Equations (3.3.5)-(3.3.8), respectively.

\section{Acylation}

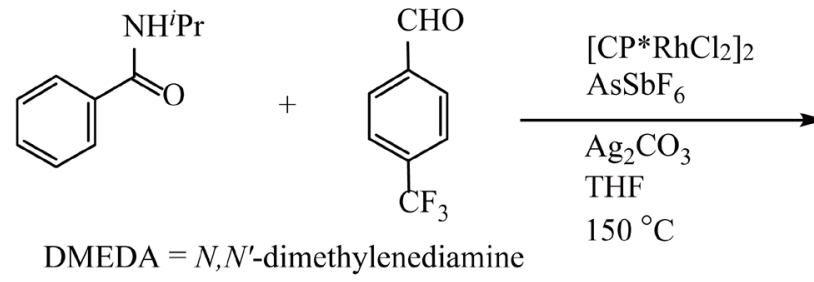<smiles>CCCC1C(=O)c2ccccc2C1(O)c1ccc(C(F)(F)F)cc1</smiles>

[148]

$83 \%$

\section{Amination}<smiles>COc1ccc(C(=O)NCCCN)cc1</smiles>

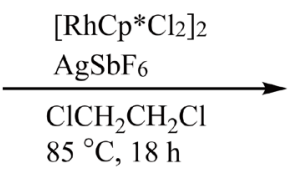

$[149$<smiles>CCCCNC(=O)c1ccccc1Nc1ccc([N+](=O)[O-])cc1</smiles> 


\section{Halogenation}

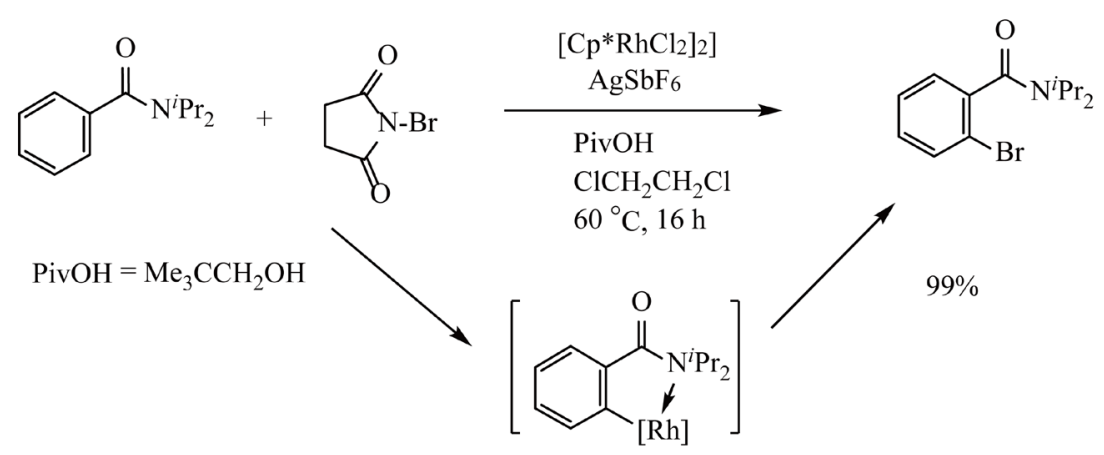

Silylation

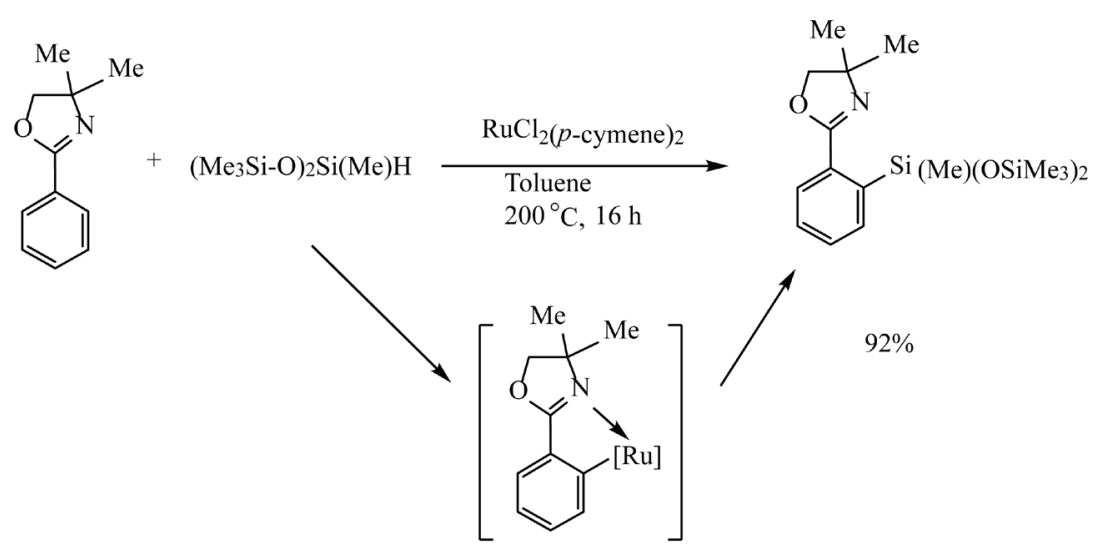

\section{Concluding Remarks}

The five-membered ring products and intermediates of cyclometalation reactions are synthesized with various types of substrates, metal compounds (69 types of meal atoms), and ancillary ligands. In particularly, we noticed the substrates such as carbenes, pincers, heterocyclic compounds and dendrimers, and on the metal compounds such as common metals and rare earth metals.

As to the carbenes, for example, first and second generation Hoveyda-Grubbs metathesis catalysts have been used as very highly active catalysts. Recently, new third Hoveyda-Grubbs catalysts (compounds 3.9) as very highly active metathesis catalysts, exhibiting very high both TNOs and TOFs, are used with the simple changing of hetroatom from $\mathrm{O}$ to $\mathrm{N}$ atom.

The pincer compounds are tridentate substrates, they are very stable and having many functionality, for example, Michael addition reactions proceed at room temperature in high yields and high TNOs by using bisoxazolinylphenyl rhodium compound $\mathbf{2 . 8}$ as the catalysts.

The heterocyclic compounds, for example, oxazolinylphenyl compounds (compounds 2.4, 2.8 and 3.3), and the compounds in Equations (3.3.2) and (3.3.8)) are highly active catalysts.

The dendrimers are expected stable, high TNO and high functional catalysts [48].

These products are usually prepared by the reactions of noble metal compounds such as $\mathrm{Pd}, \mathrm{Pt}, \mathrm{Ru}$ and $\mathrm{Rh}$ metal compounds. Recently, articles concerning common metals such as $\mathrm{Fe}, \mathrm{Ni}$ and $\mathrm{Cu}$ and main group metals such as $\mathrm{Zn}$ and $\mathrm{Al}$, and rare earth metals such a $\mathrm{Lu}, \mathrm{Eu}$ and Sm have been published. These metal compounds are expected to be used as inexpensive and special catalysts with various conventional substrates and other ligand compounds.

Finally, I believe firmly that these cyclometalation five-membered ring products and intermediates would be utilized for the development of further new industrial products in many fields such as pharmaceuticals, OLEDs, carbon dioxide utilizations, dye-sensitizer solar-cells, sensors and the other many field by utilizing their function such as catalytic activity, etc. 


\section{Acknowledgements}

The author wishes to express his sincere appreciation to Dr. Sumio Chubachi for reading the full manuscript, enhancing its accuracy and clarity, and providing much valuable constructive criticism.

\section{References}

[1] Parshall, G.W. (1970) Intramolecular Aromatic Substitution in Transition Metal Complexes. Accounts of Chemical Research, 3, 139-144. http://dx.doi.org/10.1021/ar50028a004

[2] Trofimenko, S. (1973) Some Studies of the Cyclopalladation Reaction. Inorganic Chemistry, 12, 1215-1221. http://dx.doi.org/10.1021/ic50124a001

[3] Dehand, J. and Pfeffer, M. (1976) Cyclometallated Compounds. Coordination Chemistry Reviews, 18, $327-352$. http://dx.doi.org/10.1016/S0010-8545(00)80431-2

[4] Bruce, M.I. (1977) Cyclometalation Reactions. Angewandte Chemie International Edition, 16, 73-86. http://dx.doi.org/10.1002/anie.197700731

[5] Constable, E.C. (1984) Cyclometallated Complexes Incorporating a Heterocyclic Donor Atom, the Interface of Coordination Chemistry and Organometallic Chemistry. Polyhedron, 3, 1037-1057. http://dx.doi.org/10.1016/S0277-5387(00)88056-0

[6] Ryabov, A.D. (1985) Cyclopalladated Complexes in Organic Synthesis. Synthesis, 233-252. http://dx.doi.org/10.1055/s-1985-31169

[7] Newkome, G.R., Puckett, W.E., Gupta, V.K. and Kiefer, G.E. (1986) Cyclometalation of the Platinum Metals with Nitrogen and Alkyl, Alkenyl, and Benzyl Carbon Donors. Chemical Reviews, 86, 451-451. http://dx.doi.org/10.1021/cr00072a006

[8] Dunina, V.V. and Potatov, V.M. (1988) General Principles and Characteristics of Cyclopalladation Reactions. Russian Chemical Reviews, 57, 250-269. http://dx.doi.org/10.1070/RC1988v057n03ABEH003348

[9] Van Koten, G. (1989) Tuning the Reactivity of Metals Held in a Rigid Ligand Environment. Pure and Applied Chemistry, 61, 1681-1894. http://dx.doi.org/10.1351/pac198961101681

[10] Pfeffer, M. (1990) Reactions of Cyclopalladated Compound and Alkynes: New Pathways for Organic Synthesis? Recueil des Travaux Chimques des Payes-Bas, 109, 567-576. http://dx.doi.org/10.1002/recl.19901091202

[11] Ryabov, A.D. (1990) Mechanims of Intramolecular Actination of C-H Bonds in Transition-Metal Complexes. Chemical Reviews, 90, 403-424. http://dx.doi.org/10.1021/cr00100a004

[12] Main, L. and Nicholson, B.K. (1994) Orthomanganated Aryl Ketones and Related Compounds in Organic Synthesis. Advances in Metal-Organic Chemistry, 3, 1-51.

[13] Kiplinger, J.L., Richmond, T.G. and Osterberg, C.E. (1994) Activation of Carbon-Fluorine Bonds by Metal Complexes. Chemical Reviews, 94, 373-431. http://dx.doi.org/10.1021/cr00026a005

[14] Gruter, G.-J.M., van Klink, G.P.M., Akkerman, O.S. and Bickelhaupt, F. (1995) Intramolecular Coordination in Organometallic Compouds of Groups 2, 12, and 13. Chemical Reviews, 95, 2405-2456. http://dx.doi.org/10.1021/cr00039a006

[15] Rietveld, M.H.P., Grove, D.M. and van Koten, G. (1997) Recent Advances in the Organometallic Chemistry of Aryldiamine Anions That Can Function as $N, C, N$ - and $C, N, N$-Chelating Terdentate "Pincer" Ligands: An Overview. New Journal of Chemistry, 21, 751-771.

[16] Van der Boom, M.E. and Milstein, D. (2003) Cyclometalated Phosphine-Based Pincer Complexes: Mechanistic Insight in Catalysis, Coordination, and Bond Activation. Chemical Reviews, 103, 1759-1792. http://dx.doi.org/10.1021/cr960118r

[17] Dunina, V.V. and Gorunova, O.N. (2004) Phospha Plalladacycles: Preparation Routes. Russian Chemical Reviews, 73, 309-350. http://dx.doi.org/10.1070/RC2004v073n04ABEH000839

[18] Dunina, V.V. and Gorunova, O.N. (2005) Phospha Plalladacycles: Forms of Existence and Reactions. Russian Chemical Reviews, 74, 871-913. http://dx.doi.org/10.1070/RC2005v074n10ABEH001160

[19] Dupont, J. and Consorti, C.S. (2005) The Potential of Palladacycles: More than Just Precatalysts. Chemical Reviews, 105, 2527-2571. http://dx.doi.org/10.1021/cr030681r

[20] Mohra, F., Privér, S.H., Bhargava, S.K. and Bennett, M.A. (2006) ORTHO-Metallated Transition Metal Complexes Derived from Tertiary Phosphine and Arsine Ligands. Coordination Chemistry Reviews, 250, 1851-1888. http://dx.doi.org/10.1016/j.ccr.2005.10.003

[21] Vicente, J. and Saura-Llamas, I. (2007) ORTHO-Palladation Primary Amines: The Myth Dispelled. Comments on In- 
organic Chemistry, 28, 39-72. http://dx.doi.org/10.1080/02603590701394766

[22] Moreno, I., SanMartin, R., Inés, B., Herrero, M.T. and Domínguesz, E. (2009) Recent Advances in the Use of Unsymmetrical Palladium Pincer Complexes. Current Organic Chemistry, 13, 878-895. http://dx.doi.org/10.2174/138527209788452144

[23] Djukic, J.-P., Sortais, J.-B., Barloy, L. and Pfeffer, M. (2009) Cycloruthenated Compounds—Sytesis and Applications. European Journal of Inorganic Chemistry, 2009, 817-853. http://dx.doi.org/10.1002/ejic.200801016

[24] Albrecht, M. (2010) Cyclometalation Using d-Block Transition Metals: Fundamental Aspects and Recent Trends. Chemical Reviews, 110, 576-623. http://dx.doi.org/10.1021/cr900279a

[25] Colby, D.A., Bergman, R.G. and Ellman, J.A. (2010) Rhodium-Catalyzed C-C Bond Formation via Heteroatom-Directed C-H Bond Activation. Chemical Reviews, 110, 624-655. http://dx.doi.org/10.1021/cr900005n

[26] Lyons, T.W. and Sanford, M.S. (2010) Palladium-Catalyzed Ligand-Directed C-H Functionalization Reactions. Chemical Reviews, 110, 1147-1169. http://dx.doi.org/10.1021/cr900184e

[27] Selander, N. and Szabó, K.J. (2011) Catalysis by Palladium Pincer Complexes. Chemical Reviews, 111, $2048-2076$. http://dx.doi.org/10.1021/cr1002112

[28] Pilarski, L.T. and Szabó, K.J. (2011) Palladium Pincer Complex Catalyzed Functionalization of Electrophiles. Current Organic Chemistry, 15, 3389-3414. http://dx.doi.org/10.2174/138527211797247987

[29] Aguilar, D., Cuesta, L., Nieto, S., Serrano, E. and Urriolabeitia, E.P. (2011) Orthometallaton as a Strategy in Pd-Mediated Organic Synthesis. Current Organic Chemistry, 15. 3441-3464. http://dx.doi.org/10.2174/138527211797247923

[30] Aeockiam, P.B., Bruneau, C. and Dixneuf, P.H. (2012) Ruthenium(II)-Catalyzed C-H Bond Activation and Functionalization. Chemical Reviews, 112, 5879-5918. http://dx.doi.org/10.1021/cr300153j

[31] Omae, I. (1972) Organometallic Intramolecular-Coordination Compounds containing a Carbonyl Group. Reviews on Silicon, Germanium, Tin and Lead Compounds, 1, 59-96.

[32] Omae, I. (1979) Organometallic Intramoleular-Coordination Compounds Containing a Nitrogen Donor Ligand. Chemical Reviews, 79, 287-321. http://dx.doi.org/10.1021/cr60320a001

[33] Omae, I. (1979) Organometallic Intramoleular-Coordination Compounds. Recent Aspects in the Study of Sulfur Donor Ligands. Coordination Chemical Reviews, 28, 97-115. http://dx.doi.org/10.1016/S0010-8545(00)82010-X

[34] Omae, I. (1979) Organometallic Intramoleular-Coordination Compounds. Recent Aspects in the Study of Carbonyl Donor Ligands. Chemical Field (Kagaku No Ryoiki), 33, 767-774.

[35] Omae, I. (1980) Organometallic Intramoleular-Coordination Compounds Containing a Phosphorus Donor Ligand. Coordination Chemistry Reviews, 32, 235-271. http://dx.doi.org/10.1016/S0010-8545(00)80376-8

[36] Omae, I. (1982) Organometallic Intramoleular-Coordination Compounds. Recent Aspects in the Study of Nitrogen Donor Ligands. Journal of Synthetic Organic Chemistry Japan (Yuki Gosei Kagaku Kyokaishi), 40, 147-157. http://dx.doi.org/10.5059/yukigoseikyokaishi.40.147

[37] Omae, I. (1982) Organometallic Intramoleular-Coordination Compounds Containing an Arsine Donor Ligand. Coordination Chemistry Reviews, 42, 245-257. http://dx.doi.org/10.1016/S0010-8545(00)80536-6

[38] Omae, I. (1982) Organometallic Intramoleular-Coordination Compounds Containing a Alkoxy Oxygen Donor Ligand. Chemical Industry (Kagaku Kogyo), 33, 989-996.

[39] Omae, I. (1988) Recent Studies on Organometallic Intramoleular-Coordination Compounds. Coordination Chemistry Reviews, 83, 137-167. http://dx.doi.org/10.1016/0010-8545(88)80022-5

[40] Omae, I. (1998) Kinds of Metals in Organometallic Intramolecular-Coordination Compounds. Chemical Industry (Kagaku Kogyo), 49, 303-310.

Omae, I., Aoki, A. and Horiguchi, K. (1998) Stablities of the Five-Membered Ring Structures on Organometallic Intramolecular-Coordination Compounds. Chemical Industry (Kagaku Kogyo), 49, 469-477.

[41] Omae, I. (2004) Intramoleular Five-Membered Ring Compounds and Their Applications. Coordination Chemical Reviews, 248, 995-1023. http://dx.doi.org/10.1016/j.ccr.2004.05.011

[42] Omae, I. (2004) Five-Membered Ring Compounds in Organometallic Intramolecular-Coordination Compounds, Phosphorus, Sulfur, and Silicon, 179, 891-897.

[43] Omae, I. (2007) Three Types of Reactions with Intramolecular Five-Membered Ring Compounds in Organic Synthesis. Journal Organometallic Chemistry, 692, 2608-2632. http://dx.doi.org/10.1016/j.jorganchem.2007.02.036

[44] Omae, I. (2010) Carbonyl Group-Containing Organometallic Intramolecular-Coordination Compounds. Applied Organometallic Chemistry, 24, 347-365.

[45] Omae, I. (2011) Agostic Bonds in Cyclometalation. Journal of Organometallic Chemistry, 696, 1128-1145. http://dx.doi.org/10.1016/j.jorganchem.2010.11.023 
[46] Omae, I. (2014) Applications of Five-Membered Ring Products of Cyclometalation Reactions as Anticancer Agents. Coordination Chemistry Reviews, 280, 84-95. http://dx.doi.org/10.1016/j.ccr.2014.07.019

[47] Omae, I. (2014) Unconventional Cyclometalation Reactions. Current Organic Chemistry, 18, 2776-2795. http://dx.doi.org/10.2174/1385272819666141013224601

[48] Omae, I. (2016) Applications of the Five-Membered Ring Blue Light-Emitting Iridium Products of Cyclometalation Reactions as OLEDs. Coordination Chemistry Reviews, 310, 154-169. http://dx.doi.org/10.1016/j.ccr.2015.08.009

[49] Omae, I. (2016) Carbon Dioxide Utilization by the Five-Membered Ring Products of Cyclometalation Reactions. Current Organic Chemistry, 20, 953-962. http://dx.doi.org/10.2174/1385272819666151022220954

[50] Morales-Morales, D. and Jensen, C.M. Eds. (2007) The Chemistry of Pincer Compounds. Elsevier, Amsterdam.

[51] Chatani, N. Ed. (2007) Directed Metallation. Springer, Heidelberg. http://dx.doi.org/10.1007/978-3-540-75809-9

[52] Dupont, J. and Pfeffer, M. Eds. (2008) Palladacycles, Synthesis, Characterization and Applications. Wiley-VCH, Weinheim.

[53] Van Koten, G. and Milstein, D.M. Eds. (2013) Organometallic Pincer Chemistry. Springer, Heidelberg. http://dx.doi.org/10.1007/978-3-642-31081-2

[54] Omae, I. (1986) Organometallic Intramolecular-Coordination Compounds. Elsevier, Amsterdam.

[55] Omae, I. (2014) Cyclometalation Reactions: Five-Membered Ring Products as Universal Reagents. Springer, Heidelberg. http://dx.doi.org/10.1007/978-4-431-54604-7

[56] Basolo, F. and Johnson, R. (1964) Coordination Chemistry, the Chemistry of Metal Complexes. The Benjamin/Cummings Publishing Company, London.

[57] Omae, I. (1982) Organometallic Intramolecular-Coordination Compounds Containing a Cyclopentadienyl Donor Ligand. Coordination Chemistry Reviews, 42, 31-54. http://dx.doi.org/10.1016/S0010-8545(00)80526-3

[58] Omae, I (1982) Organometallic Intramolecular-Coordination Compounds Containing a Carbon-Carbon Double Bond Donor Ligand. Angewandte Chemie International Edition, 21, 889-902. http://dx.doi.org/10.1002/anie.198208891

[59] Omae, I. (1983) Organometallic Intramolecular-Coordination Compounds Containing a Diolefin Double Bond Donor Ligand. Coordination Chemistry Reviews, 51, 1-39. http://dx.doi.org/10.1016/0010-8545(83)80025-3

[60] Omae, I. (1984) Organometallic Intramolecular-Coordination Compounds Containing a Allyl Donor Ligand. Coordination Chemistry Reviews, 53, 261-291. http://dx.doi.org/10.1016/0010-8545(84)85010-9

[61] Fisher, D.F., Barakat, A., Xin, Z., Weiss, M.E. and Peters, R. (2009) The Asymmetric Aza-Claisen Rearrangement: Development of Widely Applicable Pentaphenylferrocenyl Palladacycle Catalysts. Chemistry—A Europian Journal, 15, 8722-8741. http://dx.doi.org/10.1002/chem.200900712

[62] Albert, J., Granell, J. and Muller, G. (2006) Synthesis and Applications of Optically Active Metallacycles Derived from Primary Amines. Journal of Organometallic Chemistr, 691, 2101-2106. http://dx.doi.org/10.1016/j.jorganchem.2005.10.041

[63] Nishiyama, H. (2007) Synthesis and Use of Bisoxazolinyl-Phenyl Pincers. Chemical Society Reviews, 36, $1133-1141$. http://dx.doi.org/10.1039/b605991k

[64] Diukic, J.-P., Hijazi, A., Flack, H.D. and Bernardinelli, G. (2008) Non-Racemic (Scalemic) Planar-Chiral Five-Membered Metallacycles: Routes, Means, and Pitfalls in Their Synthesis and Characterization. Chemical Society Reviews, 37, 406-425. http://dx.doi.org/10.1039/B618557F

[65] Nishiyama, H. and Ito, J. (2010) Bis(Oxazolinyl)Phenyl Transition-Metal Complexes: Asymmetric Catalysis and Some Reactions of the Metals. Chemical Communication, 46, 203-212. http://dx.doi.org/10.1039/B918923H

[66] Dunina, V.V., Gorunova, O.N., Zykov, P.A. and Kochetkov, K.A. (2011) Cyclopalldated Complexes in Enantioselective Catalysis. Russian Chemical Reviews, 80, 51-74. http://dx.doi.org/10.1070/RC2011v080n01ABEH004151

[67] Dunina, V.V. (2011) Chiral Cyclopalladated Compounds: New Structures, Methodologies and Applications. A Personal Account. Current Organic Chemistry, 15, 3415-3440. http://dx.doi.org/10.2174/138527211797247941

[68] Hosokawa, S., Ito, J. and Nishiyama, H. (2010) A Chiral Iron Complex Containing a Bis(Oxazolinyl)Phenyl Ligand: Preparation and Asymmetric Hydrosilylation of Ketones. Organometallics, 29, 5773-5775. http://dx.doi.org/10.1021/om1009186

[69] Chen, L.-A., Xu, W., Huang, B., Ma, J., Wang, L., Xi, J., Harms, K., Gong, L. and Meggers, E. (2013) Asymmetric Catalysis with an Inert Chiral-at-Metal Iridium Complex. Journal American Chemical Society, 135, 10598-10601. http://dx.doi.org/10.1021/ja403777k

[70] Kung, K.K.-Y., Lo, K.-Y., Ko, H.-M., Li, G.-L., Leung, K.-C., Zhou, Z., Wang, M.-Z., Che, C.-M. and Wong, M.-K. (2013) Cyclometallated Gold(III) Complexes as Effective Catalysts for Synthesis of Progargylic Amines, Chiral Al- 
lenes and Isoxazoles. Advances Synthesis Catalysis, 355, 2055-2070. http://dx.doi.org/10.1002/adsc.201300005

[71] Reznichenko, A.L. and Hultzsch, K.C. (2013) $C_{1}$-Symmetric Rare-Earth-Metal Aminodiolate Complexes for intra- and Intermolecular Asymmetric Hydroamination of Alkenes. Organometallics, 32, 1394-1408. http://dx.doi.org/10.1021/om3010614

[72] Miyashita, A., Yasuda, A., Takaya, H., Toriumi, K., Ito, T., Souchi, T. and Noyori, R. (1980) Synthesis of 2.2’Bis(Diphenylphosphino)-1,1'-Binaphthyl (BINAP), an Atropisomeric Chiral Bis(Triaryl)Phosphine, and Its Use in the Rhodium(I)-Catalyzed Asymmetric Hydrogenation of .alpha.-(Acylamino)Acrylic Acids. Journal American Chemical Society, 102, 7932-7934. http://dx.doi.org/10.1021/ja00547a020

[73] Ohshima, T., Kawabata, T., Takeuchi, Y., Kakinuma, T., Iwasaki, T., Yonezawa, T., Murakami, H., NIshiyama, H. and Mashima, K. (2011) $\mathrm{C}_{1}$-Symmetric Rh/Phebox-Catalyzed Asymmetric Alkynylation of $\alpha$-Ketoesters. Angewandete Chemistry International Edition, 50, 6296-6300. http://dx.doi.org/10.1002/anie.201100252

[74] Overman, L.E., Owen, C.E. and Pavan, M.M. (2003) Catalytic Asymmetric Rearrangement of Allyic N-Aryl Trifluoroacetimidates. A Useful Method for Transforming Prochiral Allylic Alcohols to Chiral Allylic Amines. Organic Letters, 5. 1809-1812. http://dx.doi.org/10.1021/ol0271786

[75] Motoyama, Y., Koga, Y., Kobayashi, K., Aoki, K. and Nishiyama, H. (2002) Novel Asymmetric Michael Addition of $\alpha$-Cyanopropionates to Acrolein by the Use of a Bis(Oxazolinyl)Phenylstannane-Derived Rhodium(III) Complex as a Chiral Lewis Acid Catalyst. Chemistry-A Europian Journal, 8, 2968-2975. http://dx.doi.org/10.1002/1521-3765(20020703)8:13<2968::AID-CHEM2968>3.0.CO;2-6

[76] Chan, P.W.H., Cottrell, I.F. and Moloney, M.G. (1997) Conjugate Addition of Nitogen Nucleophiles to an $\alpha$, $\beta$-Unsaturated Pyrrolidinone. Tetrahedron Letter, 38, 5891-5894. http://dx.doi.org/10.1016/S0040-4039(97)01312-9

[77] Stark, M.A., Jones, G. and Richards, C.J. (2000) Cationic [2,6-Bis(2‘-Oxzolinyl)Palladium(II) Complexes: Catalysts for the Asymmetric Michael Reaction. Organometallics, 19, 1282-1291. http://dx.doi.org/10.1021/om990710h

[78] Fossey, J.S. and Richards, C.J. (2004) Synthesis of 2,6-(2-Oxazolinyl)Phenylpaatinum(II) NCN Pincer Complexes by Direct Cyclometalation. Catalysts for Carbon-Carbon Bond Formation. Organometallics, 23, 367-373. http://dx.doi.org/10.1021/om0305162

[79] Grubbs, R.H. (2004) Olefin Metathesis. Tetrahedron, 60, 7117-7140. http://dx.doi.org/10.1016/j.tet.2004.05.124

[80] Colacino, E., Martinez, J. and Lamaty, F. (2007) Preparation of NHC-Ruthenium Complexes and Their Catalytic Activity in Metathesis Reaction. Coordination Chemistry Reviews, 251, 726-764. http://dx.doi.org/10.1016/j.ccr.2006.07.017

[81] Samojlowicz, C., Bieniek, M. and Grela, K. (2009) Ruthenium-Based Olefin Methathesis Catalysts N-Heterocyclic Carbene Ligands. Chemical Reviews, 109, 3708-3742. http://dx.doi.org/10.1021/cr800524f

[82] Vougiokalakis, G.C. and Grubbs, R. (2010) Rhthenium-Based Heterocyclic Carbene-Coordinated Olefin Metathesis Catalysts. Chemical Reviews, 110, 1746-1787. http://dx.doi.org/10.1021/cr9002424

[83] Kress S. and Blechert S. (2012) Asymmetric catalysts for stereocontrolled olefin metathesis reactions. Chemical Society Reviews, 41, 4389-4408. http://dx.doi.org/10.1039/c2cs15348c

[84] Miki, K., Inoue, T. and Ohe, K. (2013) Metathesis Polymerization-Based Synthesis of Functionalized Polymers Aiming at Medicinal Application. Journal of Synthetic Organic Chemistry Japan (Yuki Gosei Kagaku Kyokaishi), 71, 601615. http://dx.doi.org/10.5059/yukigoseikyokaishi.71.601

[85] Grubbs, R.H. Ed. (2003) Handbook of Metathesis. Vol. 1-3, Wiley-VCH, Weinheim. http://dx.doi.org/10.1002/9783527619481

[86] Yao, Q. and Sheets, M. (2005) An Ionic Liquid-Tagged Second Generation Hoveyda-Grubbs Ruthenium Carbene Complex as Highly Reactive and Recyclable Catalyst for Ring-Closing Metathesis of Di-, Tri- and Tetrasubstituted Dienes. Journal of Organometallic Chemistry, 690, 3577-3584. http://dx.doi.org/10.1016/j.jorganchem.2005.03.031

[87] Garber, S.B., Kingsbury, J.S., Gray, B.L. and Hoveyda, A.H. (2000) Efficient and Recyclable Monomeric and Dendritic Ru-Based Metathesis Catalysts. Journal American Chemical Society, 122, 8168-8179. http://dx.doi.org/10.1021/ja001179g

[88] Ohshima, K. (2010) Cross-Coupling Reactions. Chemistry (Kagaku), 65, 12-17. Kagaku, S. Ed. (2010) A Chronological Table of Cross-Coupling Reactions. Chemistry (Kagaku), 65, 18-20.

[89] Herrmann, W.A., Böhm, V.P.W. and Reisinger, C.-P. (1999) Application of Palladacycles in Heck Type Reactions. Journal of Organometallic Chemistry, 576, 23-41. http://dx.doi.org/10.1016/S0022-328X(98)01050-X

[90] Littke, A.F. and Fu, G.C. (2002) Palladium-Catalyzed Coupling Reactions of Aryl Chlorides. Angewandte Chemie International Edition, 41, 4176-4211. http://dx.doi.org/10.1002/1521-3773(20021115)41:22<4176::AID-ANIE4176>3.0.CO;2-U

[91] Singleton, J.T. (2003) The Uses of Pincer Complexes in Organic Synthesis. Tetrahedron, 59, 1837-1857. 
http://dx.doi.org/10.1016/S0040-4020(02)01511-9

[92] Bedford, R.B. (2003) Palladacyclic Catalysts in C-C and C-Heteroatom Bond-Forming Reactions. The Royal Society of Chemistry, Chemical Communication, 1787-1796. http://dx.doi.org/10.1039/B211298C

[93] Beletskaya, I.P. and Cheprakov, A.V. (2004) Palladaycycles in Catalysis-A Critical Survey. Journal of Organometallic Chemistry, 689, 4055-4082. http://dx.doi.org/10.1016/j.jorganchem.2004.07.054

[94] Alonso, D.A. and Nájera, C. (2010) Oxime-Derived Palladacycles as Source of Palladium Nanoparticles. Chemical Society Reviews, 39, 2891-2902. http://dx.doi.org/10.1039/b821314n

[95] Frey, G.D., Schütz, J., Herdtweck, E. and Herrmann, W.A. (2005) Synthesis and Characterization of $N$-Heterocyclic Carbene Phospha-Palladacycles and Their Propterties in Heck Catalysis. Organometallics, 24, 4416-4426. http://dx.doi.org/10.1021/om049001g

[96] Botella, L. and Najera, C. (2002) Cross-Coupling Reactions with Boronic Acids in Water Catalyzedby Oxime-Derived Palladacycles. Journal of Organometallic Chemistry, 663, 46-57. http://dx.doi.org/10.1016/S0022-328X(02)01727-8

[97] Albisson, D.A., Bedford, R.B., Lawrence, S.E. and Scully P.N. (1998) Orthopalldated Triaryl Phosphite Complexes as Highly Active Catalysts in Biaryl Coupling Reactions. Chemical Communications, 2095-2096. http://dx.doi.org/10.1039/a806041j

[98] Liang, L.-C., Chien, P.-S. and Huang, M.-H. (2005) Catalytic Suzuki Coupling Reactions by Amido Phosphine Complexes of Palladium. Organometallics, 24, 353-357. http://dx.doi.org/10.1021/om0492395

[99] Juliá-Hernández, F., Arcas, A. and Vicente, J. (2012) Providing Support in Favor of the Existence of a Pd ${ }^{\mathrm{II}} / \mathrm{Pd}^{\mathrm{IV}} \mathrm{Cata}^{-}$ lytic Cycle in a Heck-Type Reaction. Chemistry-A Europian Journal, 18, 7780-7786. http://dx.doi.org/10.1002/chem.201103679

[100] Tsubomura, T., Chiba, M., Nagai, S., Ishihira, M., Matsumoto, K. and Tsukuda, T. (2011) Dinuclear Macrocyclic Palladium Complexes Having Pincer Coordinating Groups and Their Catalytic Properties in Misoroki-Heck Reactions. Journal of Organometallic Chemistry, 696, 3657-3661. http://dx.doi.org/10.1016/j.jorganchem.2011.08.024

[101] Pérez, M.A., Quijada, R., Ortega-Jiménezm, F. and Alvarez-Toledano, C. (2005) Cyclopalldated Complexes Derivates of Phenylhydrazones and Their Use as Catalysts in Ethylene Polymerization. Journal of Molecular Catalysis A: Chemical, 226, 291-295. http://dx.doi.org/10.1016/j.molcata.2004.08.013

[102] Frazier, K.A., Froese, R.D., He, Y., Klosin, J., Theriaut, C.N., Vosejpka, P.C. and Zhou, Z. (2011) Pyridylamido Hafnium and Zirconium Complexes: Synthesis, Dynamic Behavior, and Ethylene/1-Octene and Propylene Polymerization Reactions. Organometallics, 30, 3318-3329. http://dx.doi.org/10.1021/om200167h

[103] Loi, Z., Gao, W., Liu, X., Luo, X., Cui, D. and Mu, Y. (2011) Pincer Chromium(II) and Chromium(III) Complexes Supported by Bis(Imino)Aryl NCN Ligands: Synthesis and Catalysis on Isoprene Polymerization. Organometallics, 30 , 752-759. http://dx.doi.org/10.1021/om1009236

[104] Baratta, W., Siega, K. and Rigo, P. (2007) Catalytic Transfer-Hydrogenation with Terdentate CNN Ruthenium Complexes: The Influence of the Base. Chemistry-A Europian Journal, 13, 7479-7486. http://dx.doi.org/10.1002/chem.200700507

[105] Engle, K.M., Mei, T.-S., Wasa, M. and Yu, J.-Q. (2012) Weak Coordination as a Powerful Means for Developing Broadly Useful C-H Functionalization Reactions. Accounts of Chemical Research, 45, 788-802. http://dx.doi.org/10.1021/ar200185g

[106] Murai, S., Kakiuchi, F., Sekine, S., Tanaka, Y., Kamatani, A., Sonoda, M. and Chatani, N. (1993) Efficient Catalytic Addition of Aromatic Carbon-Hydrogen Bonds to Olefins. Nature, 366, 529-531. http://dx.doi.org/10.1038/366529a0

[107] Borman, S. (1993) ORGANOMETALLIC SYNTESIS Aromatic Added to Alkenes in One Step. Chemical Engineering News, 6-7.

[108] Murai, S., Kakiuchi, F., Sekine, S., Tanaka, Y., Kamatani, A., Sonoda, M. and Chatani, N. (1994) Catalytic C-H/olefin Coupling. Pure \& Application Chemistry, 66, 1527-1534. http://dx.doi.org/10.1351/pac199466071527

[109] Kakiuchi, F., Tanaka, Y., Sato, T., Chatani, N. and Murai, S. (1995) Catalytic Addition of Olefinic C-H Bonds to Olefins. Chemistry Letters, 679-680. http://dx.doi.org/10.1246/cl.1995.679

[110] Kakiuchi, F., Sekine, S., Tanaka, Y., Kamatani, A., Sonoda, M., Chatani, N. and Murai, S. (1995) Catalytic Addition of Aromatic Carbon-Hydrogen Bonds to Olefins with the Aid of Ruthenium Complexes. Bulletin of the Chemical Society of Japan, 68, 62-83. http://dx.doi.org/10.1246/bcsj.68.62

[111] Sonoda, M., Kakiuchi, F., Chatani, N. and Murai, S. (1997) Ruthenium-Catalyzed Addition of Carbon-Hydrogen Bonds in Aromatic Ketones to Olefines. The Effect of Various Substituents at the Aromatic Ring. Bulletin of the Chemical Society of Japan, 70, 3117-3128. http://dx.doi.org/10.1246/bcsj.70.3117

[112] Chatani, N., Ie, Y., Kakiuchi, F. and Murai, S. (1999) $\mathrm{Ru}_{3}(\mathrm{CO})_{12}$-Catalyzed Decarbonylative Cleavage of a C-C Bond of Alkyl Phenyl Ketones. Journal Chemical Society, 121, 8645-8646. http://dx.doi.org/10.1021/ja992048m 
[113] Kakiuchi, F., Matsumoto, M., Sonoda, M., Chatani, N., Murai, S., Furukawa, N. and Seki, Y. (2000) A New Synthetic Route to Heteroarylsilanes Fia Ruthenuim-Catalyzed C-H/SiR ${ }_{3}$. Chemistry Letters, 750-751. http://dx.doi.org/10.1246/cl.2000.750

[114] Kakiuchi, F., Ohtaki, H., Sonoda, M., Chatani, N. and Murai, S. (2001) Mechanistic Study of the $\mathrm{Ru}(\mathrm{H})_{2}(\mathrm{CO})\left(\mathrm{PPh}_{3}\right)_{3^{-}}$ Catalyzed Addition of C-H Bonds in Aromatic Esters to Olefins. Chemistry Letters, 918-919. http://dx.doi.org/10.1246/cl.2001.918

[115] Kakiuchi, F. and Murai, S. (2002) Catalytic C-H/Olefin Coupling. Accounts of Chemical Reseach, 35, 826-834. http://dx.doi.org/10.1021/ar960318p

[116] Kakiuchi, F., Kan, S., Igi, K., Chatani, N. anad Murai, S. (2003) A Ruthenium-Catalyzed Reaction of Aromatic Ketones with Aryboronates: A New Method for the Arylation of Aromatic Compounds via C-H Bond Cleavage. Journal American Chemical Society, 125, 1698-1699. http://dx.doi.org/10.1021/ja029273f

[117] Park, S.H., Kim, J.Y. and Chang, C. (2011) Rhodium-Catalyzed Selective Olefination of Arene Esters via C-H Bond Activation. Organic Letters, 13, 2372-2375. http://dx.doi.org/10.1021/ol200600p

[118] Girling, I.R. and Widdowson, D.A. (1982) Cyclopalladated Imines in Synthesis: The Preparation of Unsymmetrical Stilbenes and 3-Arylisoquinolones. Teterahedron Letters, 23, 1957-1960. http://dx.doi.org/10.1016/S0040-4039(00)87233-0

[119] Jun, C.-H., Lee, H. and Hong, J.-B. (1997) Chelation-Assisted Intermoleular Hydroacyclation: Direct Synthesis of Ketone from Aldehyde and 1-Alkene. Journal Organic Chemistry, 62, 1200-1201. http://dx.doi.org/10.1021/jo961887d

[120] Harbourne, D.A. and Stone, F.G.A. (1968) Chemistry of the Metal Carbonyls. Part XLVII. Reactions of 3,3,3-Tri-fluoropropyne. Journal Chemical Society A, 1765-1771. http://dx.doi.org/10.1039/j19680001765

[121] DeShong, P., Sidler, D.R., Rybczynki, P.J., Slough, G.A. and Rheingold, A.L. (1988) A General Method for the Preparation of Carbonyl Compounds and Butenolides from Organomanganese Pentacarbonyl Complexes. Journal American Chemical Society, 110, 2575-2585. http://dx.doi.org/10.1021/ja00216a034

[122] Cassar, D.J., Ilyashenki, G., Ismail, M., Woods, J., Hughes, D.L. and Richards C.J. (2013) Enantioselective Synthesis and Application to the Allylic Imidate Rearrangement of Amine-Coordinated Palladacycle Catalysts of Cobalt Sandwich Complexes. Chemistry—A Europian Journal, 19, 17951-17962. http://dx.doi.org/10.1002/chem.201302922

[123] Chanthamath, S., Nguyen, D.T., Shibatomi, K. and Iwasa, S. (2013) Highly Enantioselective Synthesis of Cyclopropylamine Derivatives via Ru(II)-Phenox-Catalyzed Direct Asymmetric Cyclopropanation of Vinylcarbamates. Organic Letters, 15, 772-775. http://dx.doi.org/10.1021/ol303404c

[124] Jia, Y.-X., Li, B.-B., Li, Y., Pullarkat, S.A., Xu, K., Hirato, H. and Leung, P.-H. (2014) Stereoelectronic and Catalytic Properties of Chiral Cyclometalated Phos-Palladium and -Platinum Complexes. Organometallics, 33, 6053-6058. http://dx.doi.org/10.1021/om500662q

[125] Sabater, S., Mata, J.A. and Peris, E. (2013) Chiral Palladacycles with N-Heterocyclic Carbene Ligands as Catalysts for Asymmetric Hydrophosphination. Organometallics, 32, 1112-1120. http://dx.doi.org/10.1021/om400007a

[126] Huo, H., Fu. C., Harms, K. and Meggers, E. (2014) Asymmetric Catalysis with Substitutionally Labile yet Stereochemically Stable Chiral-at-Metal Iridiium(III) Complex. Journal American Chemical Society, 136, 2990-2993. http://dx.doi.org/10.1021/ja4132505

[127] Toribatake, K. and Nishiyama, H. (2013) Asymmetric Diboration of Teminal Alkenes with a Rhodium Catalyst and Subsequent Oxidation: Enantioselective Synthesis of Optically Active 1,2-Diols. Angewandte Chemie International Editions, 52, 11011-11015. http://dx.doi.org/10.1002/anie.201305181

[128] Schramm, Y., Barrios-Landeros, F. and Pfaltz, A. (2013) Discovery of an iridacycle catalyst with improved reactivity and enantioselectivity in the hydrogenation of dialkyl ketimines. Chemical Science, 4, 2760-2766. http://dx.doi.org/10.1039/c3sc50587a

[129] Chew, R.J., Huang, Y., Li, Y., Pullarkat, S.A. and Leung, P.-H. (2013) Enantioselective Addition of Diphenylphosphine to 3-Methyl-4-Nitro-5-Alkenylisoxazoles. Advance Synthesis Catalysis, 355, 1403-1408. http://dx.doi.org/10.1002/adsc.201300164

[130] Ito, J. and Nishiyama, H. (2013) Asymmetric Catalysis Mediated by Optically Active Bis(Ozazolinyl)Phenyl Metal Complexes. Journal of Synthetic Organic Chemistry Japan (Yuki Gosei Kagaku Kyokaishi), 71, 791-803. http://dx.doi.org/10.5059/yukigoseikyokaishi.71.791

[131] Cheow, Y.L., Pullarkat, S.A., Li, Y. and Leung, P.-H. (2012) Asymmetric Hydroarsilnation Reactions toward Synthesis of Alcohol Functionalized C-Chiral As-P Lingads Promoted by Chiral Cyclomeallated Complexes. Journal of Organometallic Chemistry, 696, 4215-4220. http://dx.doi.org/10.1016/j.jorganchem.2011.09.016

[132] Ito, J., Teshima, T. and Nishiyama, H. (2012) Enhancement of Enantioselectivity by Alcohol Additives in Asymmetric Hydrogenation Woth Bis(Oxazolinyl)Phenyl Ruthenium Catalysts. Chemical Communications, 48, 1105-1107. http://dx.doi.org/10.1039/C1CC16057E 
[133] Yang, Z., Liu, D., Liu, Y., Sugiya, M., Imamoto, T. and Zhang, W. (2015) Synthesis and Structural Chraracterization of Nickel Complexes Possessing P-Stereogenic Pincer Scaffolds and Their Application in Asymmetric Aza-Michael Reactions. Organometallics, 34, 1228-1237. http://dx.doi.org/10.1021/om501287k

[134] Peeck, L.H., Savka, R.D. and Plenio, H. (2012) Fast Olefin Metathesis at Low Catalyst Loading. Chemistry-A Europian Journal, 18, 12845-12853. http://dx.doi.org/10.1002/chem.201201010

[135] Juliá-Hernández, F., Arcas, A. and Vicente, J. (2012) Providing Support in Favor of the Existence of a Pd $/ \mathrm{P}^{\mathrm{IV}}$ Catalytic Cycle in a Heck-Type Reaction. Chemistry-A Europian Journal, 18, 7780-7786. http://dx.doi.org/10.1002/chem.201103679

[136] Tsubomura, T., Chiba, M., Nagai, S., Ishihira, M., Matsumoto, K. and Tsukuda, T. (2011) Dinuclear Macrocyclic Palladium Complexes Having Pincer Coordinating Groups and Their Catalystic Properties in Mizoki-Heck Reactions. Journal of Organometallic Chemistry, 696, 3657-3661. http://dx.doi.org/10.1016/j.jorganchem.2011.08.024

[137] Kozlov, V.A., Aleksanyan, D.V., Neyyubina, Y.V., Lyssenko, K.A., Petrovskii, P.V., Vasil’ev, A.A. and Odinets, I.L. (2011) Hybrid Thiophosphoryl-Benzothiazole Palladium SCN-Pincer Complexes: Synthesis and Effect of Structure Modifications on Catalytic Performancein the Suzuki Cross-Coupling. Organometallics, 30, 2920-2932. http://dx.doi.org/10.1021/om101012r

[138] Yu, A., Li, X., Peng, D., Wu, Y. and Chang, J. (2012) Cyclopalladated Ferrocenylimine as an Efficient Catalyst for the Syntheses of Diarylmethane Derivatives. Applied Organometallic Chemistry, 26, 301-304. http://dx.doi.org/10.1002/aoc.2859

[139] McGowan, K.P. and Veige, A.S. (2012) A Neutral Trianionic Pincer [NCN]Cr ${ }^{\mathrm{IV}}-\mathrm{Me}$ Complex as a Highly Ethylene Polymerization Precatalyst. Journal of Organometallic Chemistry, 711, 10-14. http://dx.doi.org/10.1016/j.jorganchem.2012.03.007

[140] Luconi, L., Rossin, A., Tuci, G., Tritto, I., Boggioni, L., Klosin, J.J., Theriault, C.N. and Giambastiani, G. (2012) Facing Unexpected Reactivity Pathswith $\mathrm{Zr}^{\mathrm{IV}}$-Pyridylamido Polymerization Catlysts. Chemistry-A Europian Journal, 18, 671-687. http://dx.doi.org/10.1002/chem.201102194

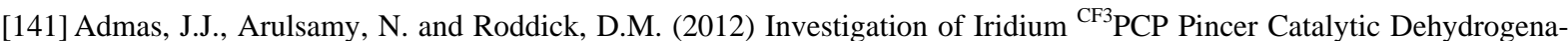
tion and Decarbonylation Chemistry. Organometallics, 31, 1439-1447. http://dx.doi.org/10.1021/om2011886

[142] Du, W., Wang, L., Wu, P. and Yu, Z. (2012) A Versatile Ruthenium(II) Complex Catalyst for Transfer Hydrogenatation of Ketones and Oppenauer-Type Oxidaton of Alcohols. Chemistry - A Europian Journal, 18, 11550-11554. http://dx.doi.org/10.1002/chem.201201938

[143] Li, L., Yu, P., Cheng, J., Chen, F. and Pan, C. (2012) Copper(II)-Catallyzed ORTHO-Benzoxylation of 2-Arylpyridines with Sodium Carboxylates. Chemistry Letters, 41, 600-602. http://dx.doi.org/10.1246/cl.2012.600

[144] Song, W. and Ackermann, L. (2012) Cobalt-Catalyzed Direct Arylation and Benzylation by C-H/C-O Cleavage with Sulfamates, Carbamates, and Phosphates. Angewandte Chemie International Edition, 51, 8251-8254. http://dx.doi.org/10.1002/anie.201202466

[145] Schröder, N., Besset, T. and Glorius, F. (2012) Synthesis of Olefin-Oxazoline Ligands (OlefOx) by Rhodium(III)-Catalyzed Oxidative Olefination. Advances Synthesis Catalysis, 354, 579-583. http://dx.doi.org/10.1002/adsc.201100711

[146] Wang, C., Chen, H., Wang, Z., Chen, J. and Huang, Y. (2012) Rhodium (III)-Catalyzed C-H Activation of Arenes Using a Versatile and Removable Triazene Directing Group. Angewandte Chemie International Edition, 51, $7242-7245$. http://dx.doi.org/10.1002/anie.201203230

[147] Kuninobu, Y. and Takai, K. (2012) Development of Novel and Highly Efficient Methods to Construct Carbon-Carbon Bonds Using Group 7 Transition-Metal Catalysts. Bulletin of the Chemical Society of Japan, 85, 656-671. http://dx.doi.org/10.1246/bcsj.20120015

[148] Sharma, S., Park, E., Park, J. and Kim, I.S. (2012) Tandem Rh(III)-Cata;used Oxidative Acylation of Secondary Benzamides with Aldehydes and Intramolecular Cyclization: The Direct Synthesis of 3-Hydroxyisoindolin-1-Ones. Organic Letters, 14, 906-909. http://dx.doi.org/10.1021/ol2034228

[149] Ryu, J., Shin, K., Park, S.H., Kim, J.Y. and Chang, S. (2012) Rhodium-Catalyzed Direct C-H Amination of Benzamides with Aryl Azides: A Synthetic Route to Diarylamines. Angewandte Chemie International Edition, 51, 99049908. http://dx.doi.org/10.1002/anie.201205723

[150] Niu, L., Yang, H., Yang, D. and Fu, H. (2012) Fuctionalizations of Aryl C-H Bonds in 2-Arylpyridines via Sequential Borylation and Coper Catalysis. Advances Synthesis Catalysis, 354, 2211-2217. http://dx.doi.org/10.1002/adsc.201100930

[151] Sakurai, T., Matsuoka, Y., Hanataka, T., Fukuyama, N., Namikoshi, T., Watanabe, S. and Murata, M. (2012) Ruthenium-Catalyzed ORTHO-Selective Aromatic C-H Silylation: Acceptorless Dehydrogenative Coupling of Hydrosilanes. Chemistry Letters, 41, 374-376. http://dx.doi.org/10.1246/cl.2012.374 